NBER WORKING PAPER SERIES

\title{
LIQUIDITY AND FOREIGN ASSET MANAGEMENT CHALLENGES FOR LATIN AMERICAN COUNTRIES
}

\author{
Joshua Aizenman \\ Daniel Riera-Crichton \\ Working Paper 20646 \\ http://www.nber.org/papers/w20646 \\ NATIONAL BUREAU OF ECONOMIC RESEARCH \\ 1050 Massachusetts Avenue \\ Cambridge, MA 02138 \\ October 2014
}

Prepared for the 18th Annual Conference of the Central Bank of Chile "Commodity Prices and Macroeconomic Policy," October 2014, Santiago, Chile [Rodrigo Caputo and Roberto Chang, eds.]. Insightful comments by Martin Bodenstein, Jose De Gregorio, Pablo Garcia and Governor Rodrigo Vergara are gratefully acknowledged. Support from the Bank of Chile is gratefully acknowledged. The views expressed herein are those of the authors and do not necessarily reflect the views of the National Bureau of Economic Research and the Bank of Chile.

NBER working papers are circulated for discussion and comment purposes. They have not been peerreviewed or been subject to the review by the NBER Board of Directors that accompanies official NBER publications.

(C) 2014 by Joshua Aizenman and Daniel Riera-Crichton. All rights reserved. Short sections of text, not to exceed two paragraphs, may be quoted without explicit permission provided that full credit, including $(\subset)$ notice, is given to the source. 
Liquidity and Foreign Asset Management Challenges for Latin American Countries

Joshua Aizenman and Daniel Riera-Crichton

NBER Working Paper No. 20646

October 2014

JEL No. F15,F31,F32,F36,O13

\begin{abstract}
$\underline{\text { ABSTRACT }}$
We analyze the degree to which the growing importance of sovereign wealth funds [SWFs] and the diffusion of inflation targeting and augmented Taylor rules have impacted the post crisis adjustment of Latin American Countries (LATAM) to the challenges associated with terms of trade and financial shocks. We confirm that active international reserves management reduces the effects of transitory Commodity Terms of Trade (CTOT) shocks to the real exchange rate [REER] and the real GDP in LATAM economies. These buffer effects work more against the risks of real appreciation than against depreciations, under relatively high levels of external debt and in economies that are less open to trade. Fixed exchange regimes act as a substitute policy to reserve accumulation. In contrast to reserves, SWFs buffers the REER from CTOT shocks with fixed exchange rate regimes and in relatively closed economies. The buffer effect of reserve accumulation appears to be strongest during the 1980-2007 period. While the stock of reserves fails to smooth the transmission of CTOT shocks to REER during the Global Financial Crisis (2008-2009), SWFs stepped up as substitutes to traditional reserve assets. The international reserve buffering role resumes during the post-great recession period (2010-2013), but not at the levels observed prior to the crisis. We observe a "substitution" between reserves and SWFs, where SWFs take over the buffering role of the REER and the real GDP during the Great Recession and the post-Great Recession period. Inflation targeting (IT) policy matters: IT countries give up the use of reserves to buffer against CTOT shocks, relegating this role to the SWFs. In LATAM countries that follow augmented Taylor rules, their monetary authorities place large weights on output gaps; while inflation gains importance for IT countries. Countries switch from REER stabilization targets to inflation targets when committing to a formal IT rule. SWFs may provide IT countries with an alternative form of liquidity management against foreign shocks when traditional reserves are committed to other macroeconomic goals. This is true for both REER and output growth stabilization.
\end{abstract}

Joshua Aizenman

Economics and SIR

USC

University Park

Los Angeles, CA 90089-0043

and NBER

aizenman@usc.edu

Daniel Riera-Crichton

Department of Economics, Bates College

Andrews Road 2

Office 237 Pettingill Hall

Lewiston, ME 04240

drieracr@bates.edu 


\section{Introduction}

The Global Financial Crisis put to the fore the challenges of managing liquidity and foreign assets at times of heightened volatility. Earlier concerns of some observers regarding the costs of precautionary hoarding notwithstanding, the Global Financial Crisis (GFC) validated the buffer value of international reserves and active management of buffer funds. These issues are especially pertinent for commodity exporters, where the high volatility of their commodity terms of trade translates into large shocks impacting the real exchange rate, and the GDP. The history of Latin American countries provides ample examples where adverse terms of trade shocks terminated spells of 'good time,' leading to capital flight and financial crises.

Intriguingly, 'this time has been different' for countries that followed during the 2000s the dictum of "save for rainy day," opting for counter-cyclical macro policies, Chile being the prime example of it [Céspedes and Velasco $(2012,2014)]$. Frankel (2011) found that since 2000, fiscal policy in Chile has been governed by a structural budget rule that has succeeded in implementing countercyclical fiscal policy. ${ }^{1}$ Furthermore, Frankel, Vegh and Vuletin (2011) found that, over the last decade, about a third of the developing world has been become countercyclical.

In commodity exporting countries, pro-active liquidity, exchange rate and foreign assets management have supported such fiscal policy. Using the pre GFC data, Aizenman and Riera Crichton (2008) found that international reserves cushion the impact of terms-of-trade shocks on the real exchange rate (REER), and that this effect is especially significant for countries exporting natural resources. Financial depth reduces the buffer role of international reserves in developing countries. In a more detailed analysis, Aizenman, Edwards and Riera-Crichton (2012) found that active reserve management not only lowers the short run impact of commodity terms of trade (CTOT) shocks significantly, but also affects the long run adjustment of REER, effectively lowering its volatility. Relatively small increases in the average holdings of reserves by Latin American economies, to levels still well below other emerging regions current averages, provided a policy tool as effective as a fixed exchange rate regime in insulating the economy from CTOT shocks. Reserve management could be an effective alternative to fiscal or currency policies for relatively trade closed countries and economies with relatively poor institutions or high government debt. Céspedes and Velasco (2012), using

\footnotetext{
${ }^{1}$ A crucial ingredient accounting for Chile's success is the official estimates of trend output and the 10-year price of copper - which are key to the decomposition of the budget in Chile into structural versus cyclical components - are made by independent expert panels and thus insulated from the political process.
} 
commodity price boom and bust episodes, provided empirical evidence that commodity price shocks have a significant impact on output and investment dynamics. Economies with more flexible exchange rate regimes exhibit less pronounced responses of output during these episodes. They also found that the impact of those shocks on investment tends to be larger for economies with less developed financial markets. Moreover, international reserve accumulation, more stable political systems, and less open capital accounts tend to reduce the real exchange rate appreciation (depreciation) in episodes of commodity price booms (busts), respectively.

The purpose of this paper is to revisit these issues, extending earlier analysis by looking at the degree to which the more recent data (up to 2013), and the new institutional developments validate the earlier results that relied on pre-GFC data. Specifically, we analyze the degree to which the growing importance of sovereign wealth funds [SWFs], and the diffusion of inflation targeting and augmented Taylor rules have impacted the post crisis adjustment of LATAM to the challenges associated with terms of trade and financial shocks. ${ }^{2}$

Extending the dataset to 2013, we are able to replicate our previous results: stock of reserves and active management reduce the effects of transitory Commodity Terms of Trade (CTOT) shocks to real exchange rate in LATAM economies. This "buffer effect" seems to work more against risk of real appreciation than against risks of depreciations. Fixed exchange regimes acts as a substitute policy to reserve accumulation, and this buffering policy seems to work under relatively high levels of external debt, and in economics that are less open to trade. We confirm the income effects of CTOT - positive correlation of CTOT shocks and the real GDP growth. The positive association between the two seems to be stronger with negative shocks, for low debt and opener economies. Accumulation (deaccumulation) of reserves helps in buffering the transmission of positive (negative) CTOT shocks to output, respectively.

SWFs add new dimensions to foreign asset managements. In contrast to reserves, SWFs seem important to buffer the real exchange rate [REER] from CTOT shocks with fixed exchange rate regimes and in relatively closed economies. SWFs also reinforce the effects of CTOT shocks on real output during negative shocks with fixed exchange rate regimes, and buffer the effect for relatively high external debt levels. Our buffer story seems to show its strongest version during the 80's, 90's and the end of the Great Moderation (2003-2007). Yet, during the great recession (2008-2009) we observe

\footnotetext{
${ }^{2}$ See Aizenman and Glick (2010) for overview of the diffusion of SWFs, and possible division of labor between SWFs and Central Banks. See Mishkin and Schmidt-Hebbel (2007), Aizenman, Hutchison and Noy (2011) and Céspedes, Chang, and Velasco (2012) for analysis on Inflation Targeting in practice.
} 
disconnect between CTOT and REER, and the role of reserves. The REER-CTOT relationship seems to resume during the post-great recession period (2010-2013) and reserve buffering returns but not at the levels observed previous to the crisis. The same story applies for active use of reserves, except that our buffer story returns in a stronger fashion during the post-recession period.

There seems to be a "substitution" between reserves and SWF, where SWFs take over the buffering of the REER and the real GDP during the Great Recession and the post-Great Recession period. Inflation targeting policy seems to matter, potentially diverting resources to the preservation of domestic price stability: IT countries seems to give up the use of reserves to buffer against CTOT shocks, relegating this role to the SWFs. In LATAM countries that seem to follow augmented Taylor rule, their monetary authorities seem to place large weight of output gaps; while inflation seems to gain importance for IT countries. The nature of the regime matters - non IT countries seem to switch from REER stabilization target to an inflation target when committing to a formal IT rule.

The rest of the paper is organized as follows: In Section 2, we define the data used in the paper as well as present a set of summary statistics describing the evolution of external liquidity as well as CTOT shocks over the last three decades. Section 3 presents our econometric strategy to uncover the way CTOT shocks affect macroeconomic performance measures such as the real exchange rates and Output growth, both in the short and long runs. We also show the proposed methods to capture the role of international reserves in smoothing temporary TOT shocks under a set of alternative macroeconomic regimes. In Section 4, we discuss our econometric results from the analysis of the buffering effect from the stock of reserves and the stock of sovereign wealth funds. These results include an investigation of the buffer effect of liquidity management following positive versus negative CTOT shocks, under different exchange rate regimes, different stocks of external debt and different degrees of trade openness. Section 5 looks at the changes in the CTOT-REER and CTOT-Growth relationship as well as our buffer story over different sample periods. Specifically, we look at the turbulent period from 1980 to 2002, the Great Moderation, the Great Recession and the period following the global crisis up to the present. Section 6 looks at the relationship between reserves and sovereign wealth funds as competing tools for international liquidity management. Section 7 explores the role of other monetary policies implemented in Latin American economies in the last two decades. The section focuses on the adoption of inflation rules by half the countries in our sample. Section 8 concludes. 


\section{Macroeconomic performance, Commodity TOT shocks and liquidity management in Latin America}

Looking at the macroeconomic performance of the largest economies (LAC-7) in Latin America over the last two decades as shown in Table 1, we see that "this time was really different". LAC-7 economies did experience a slowdown in growth and increase in volatility during the Great Recession relative to the "good times" of the Great Moderation. Nevertheless, the slowdown did not turn into a crash as in previous occasions and most countries continued to experience real appreciations against the dollar throughout the worst of the crisis. Furthermore, the recovery was "fast and furious" with average rates of annual growth above five percent, rates of real appreciation of almost three and a half percent per year and lower macroeconomic volatility than in the Great Moderation. In this paper we investigate the role of active liquidity management in this success story.

Traditionally, one of the main transmission mechanisms of global real shocks to Latin American economies has been sudden changes in relative international prices. In this paper, we use a "commodity terms of trade" (CTOT) data set to analyze the way in which shocks to commodity prices affect key macroeconomic performance measures such as changes in the Real Effective Exchange Rate (REER) or Output Growth. Our analysis focuses on the twelve largest Latin American economies: Argentina, Bolivia, Brazil, Chile, Colombia, Costa Rica, Ecuador, Mexico, Paraguay, Peru, Uruguay and Venezuela. As shown in previous work, this set of emerging countries has the highest volatility in CTOT. Our current work covers the period 1980-2014 but focuses special attention to the period of relatively low volatility before the great recession, dubbed the end of the great moderation (2002-2007), the great recession (2008-2009) and the period post great recession (2010-2013). Our key measure, the concept of "commodity terms of trade", follows Ricci et. al (2008), and differs from the traditional measure in that it only includes the relative prices of a country's commodity exports and imports, weighted by their country specific GDP shares. By excluding industrial goods, and concentrating on commodity prices, we focus on the most volatile component of import and exports prices. Specifically, this commodity terms-of-trade data set was constructed as follows: $C T O T_{i}=\prod_{j}\left(P_{j} / M U V\right)^{X_{j}^{j}} / \prod_{j}\left(P_{j} / M U V\right)^{M_{j}^{j}}$, where $P j$ is the price index for six commodity categories (food, fuels, agricultural raw materials, metals, gold, and beverages), and $\left(X_{j}^{i}, M_{j}^{i}\right)$ are the average shares of commodity $j$ in country $i$ 's exports and imports over GDP for the period 1980 through 2012, respectively. Commodity prices are deflated by the manufacturing unit value index $(M U V)$. Since $X_{j}^{i}$ and $M_{j}^{i}$ are averaged over time, the movements in 
CTOT are invariant to changes in export and import volumes in response to price fluctuations, and thus, isolate the impact of commodity prices on a country's terms of trade. ${ }^{3}$ Another useful property of this measure of CTOT arises from the use of export/import over GDP as our weights, this allows us to reinterpret CTOT shocks as income shocks to the home economy and builds a direct link to effects on aggregate income and production.

Figure 1gives us an overview of the evolution of CTOT shocks volatility overtime as well as the accumulation of international liquidity and composition of this liquidity by Latin American economies over the last three decades. While CTOT shock volatility doubled during the Great Recession, volatility was already persistently high across the previous twenty years. In spite of this high volatility, LATAM economies managed to achieve low output and REER volatility during the last decades, including the Great Recession. Part of this success may have been achieved thanks to a set of countercyclical fiscal policies and, more relevant to our work, a set of monetary policies dedicated to carefully manage international liquidity in order to lower price and output volatility. In this light, figure 1A shows how Latin American economies had started to accumulate large amounts of foreign reserves well before the last crisis. This accumulation drove LATAM economies to move from an average stock of reserves of 7.5 percent of GDP before the Great Moderation to more than 15\% after the Great Recession.

Figure 1B showcases the appearance of stabilization sovereign wealth funds (SWF) as an alternative source of International liquidity. Most of these SWFs acted as automatic stabilizers following some fiscal rule dedicated to manage the windfalls from abnormal high prices of the commodities typically exported by each country. Table 2 in the appendix depicts the SWF used in this analysis.

Figure 1C shows the country composition of the aggregate balance of these stabilization funds in the region. While Chile has been the clear leader of the pack, accumulating close to 20 billion dollars in its copper fund before the crisis, other countries like Mexico, Colombia and later in the sample Peru have been increasing their SWFs thanks to windfalls from their energy (oil and gas) funds. Venezuela was able to accumulate a large amount of funds in the early 2000's but then their fund was liquidated and has not been active since. Another relevant policy change adopted by LATAM countries during the nineties was a set of explicit inflation targets. As shown in table 3 , up to half of the countries in our

\footnotetext{
${ }^{3}$ By construction, a percentage increase (decrease) in the commodity terms of trade measure is approximately equal to the aggregate net trade gain (loss) relative to GDP from changes in real individual commodity prices (see Spatafora and Tytell (2009)). See the Appendix of NBER working paper \# 17692 for further details regarding the derivation of CTOT, Data Definitions and sources.
} 
sample became inflation targeters. Potentially, Inflation targeting represents an important part of our buffer story since inflation-targeting (IT) countries may to deviate resources from REER stabilization to internal price stabilization.

\section{Macroeconomic adjustment and commodity terms of trade shocks}

Following previous work, in this paper we use a fixed effects error correction model to capture the effects of CTOT shocks and the dynamic adjustment of REER and Output Growth. Our basic framework is represented by equation (1):

$\Delta \operatorname{Ln}(X)_{i t}=\alpha_{i}+\beta_{1} \Delta \operatorname{Ln}(X)_{i t-1}+\beta_{2} E C M X_{i t-1}+\left[\theta_{1}+\theta_{2} Y_{i t-1}\right]$ TCTOT $_{i t-1}+\beta_{2} Y_{i t-1}+\varepsilon_{i t}$

where $\mathrm{X}$ corresponds to one of our two measure of macroeconomic performance: 1) REER, the effective (trade weighted) real exchange rate $^{4}$. 2) Real GDP. ECTX is the error correction term for (the logarithm of) the $\mathrm{X}$. As usual, this term is defined as the $\log$ deviations of $\mathrm{X}$ from its equilibrium value. In order to compute the equilibrium/long-run REER, we use a co-integrating approach. ${ }^{5}$ The long run value of output growth is obtained applying an HP Filter to the original series with a smoothing parameter set at 1600. Similarly, the term TCTOT represents transitory CTOT shocks, and is defined as the log deviations of current CTOT from its long run value. The latter, again, is obtained applying an HP Filter to the original series with a smoothing parameter set at 1600 . Finally, Y represents our liquidity measure. In this paper we will use the stock of international reserves to GDP ratio, the stock of SWF to GDP ratio and the change of these ratios as our proxies for liquidity management policy.

To investigate the potential differences in our buffer story over different sample periods, different macroeconomic/policy structures or asymmetric underlying shocks, we use another layer of nonlinearities to our approach:

$\Delta \operatorname{Ln}(X)_{i t}=\alpha_{i}+\beta_{1} \Delta \operatorname{Ln}(X)_{i t-1}+\beta_{2} E C M X_{i t-1}+\left[\left(\theta_{2}^{*} Z\right)+\left(\theta_{4}^{*} Z\right) Y_{i t-1}\right] \operatorname{TCTOT}_{i t-1}+\beta_{2} Y_{i t-1}+\varepsilon_{i t}$

\footnotetext{
${ }^{4}$ For the rest of the empirical section REER is defined as foreign currency in terms of the domestic currency, e.g. an increase in REER corresponds to a real appreciation of the domestic currency

${ }^{5}$ See Edwards (1989), Montiel (1999) derivation long-run REER is detailed in the appendix.
} 
Where $\mathrm{Z}$ is defined as a vector of dummy variables that splits the regression by sample period or by different economic structure such as degree of trade openness, indebtedness or exchange rate regime.

To provide a more dynamic look of the effects of CTOT shocks to REER and Output and the potential for our buffering effect under different conditions, we set up a series of accumulated impulse response functions (IRF). To build these IRF, we follow the single-equation approach advocated by Jorda (2005) and Stock and Watson (2007), which does not impose the dynamic restrictions implicitly embedded in the SVAR methodology and can conveniently accommodate non-linearities in the response function. We use these linear local projections (LP) of real appreciation and output growth on our dynamic error correction model:

$$
\begin{aligned}
& \Delta \operatorname{Ln}(X)_{i t+h}= \\
& \alpha_{i, h}+\beta_{1, h} \Delta \operatorname{Ln}(X)_{i t-1}+\beta_{2, h} E C M X_{i t-1}+\left[\left(\theta_{2, h} * Z_{i t}\right)+\left(\theta_{4, h} * Z_{i t}\right) Y_{i t}\right] T C T O T_{i t}+\beta_{2, h} Y_{i t-1}+\varepsilon_{i t}
\end{aligned}
$$

where $\Delta \operatorname{Ln}(X)_{i t+h}=\operatorname{Ln}(X)_{i t+h}-\operatorname{Ln}(X)_{i t-1}$.It is important to note that, in this approach, each step in the accumulated IRF is obtained from a different individual equation. We thus obtain the IRF values directly from the coefficients in each equation "h". As explained in Jorda (2005), there are multiple advantages in the use of LP. In particular, LP (i) can be estimated by single-regression techniques (least-squares dummy variables or LSDV in our case), (ii) are more robust to potential misspecifications, and (iii) can accommodate highly non-linear and flexible specifications that may be impractical in a multivariate SVAR (Structural vector autoregression) context.

4. Has liquidity and foreign asset management buffered LATAM countries from external real shocks? Results from a pooled regression. 
We start our results section updating our previous work on the buffer role of foreign reserves with quarterly data until 2013. All regressions include all available data. The pooled regressions include a quarterly sample that ranges from 1980 to 2013. Not all countries have a full sample of data so our panel regressions are unbalanced. Descriptive statistics of all the variables are summarized in table 4.

Tables 5 and 6 corroborate our previous findings in our updated dataset. Table 5 reports the estimation of the basic model using the stock of reserves over GDP as a proxy for "liquidity availability". Meanwhile, table 6 uses the change in reserves as a proxy for "active reserve management". In both tables the first column confirms a positive correlation between TCOT and REER, column two showcases our basic reserve buffer story: a stock of reserve of 15 percent of GDP or a change in reserve holdings of 3 percent of GDP can, in average, decrease the REER effects of CTOT shocks on impact in half. To see the gains of this policy more clearly and in a dynamic environment we show the dynamic IRF in Figure 2. Moving the stock of reserves from 5 percent to 15 percent decreases the REER volatility (measured as the standard deviation of the point estimates on the IRF) in almost 30 percent over the following two years.

Columns 3-6 in tables 5 and 6 use dummy variables to estimate the differences in our buffer story given different policy and macroeconomic structure. Results in both tables are very similar; the buffer effect works against risk of real appreciation more than against risk of depreciation. ${ }^{6}$ Fixed exchange regimes seem to act as a substitute policy to reserve accumulation. Reserve management appears to be a more effective policy under relatively high levels of external and the buffer policy works in relatively trade close economies.

Given the potentially direct relationship between CTOT shocks and income shocks, countries may choose to stabilize output rather than REER. In tables 7 and 8 we explore the role of reserve accumulation and active reserve management as output stabilizing polices. The first column in both tables confirms the direct income effect of CTOT shocks with a strong positive correlation between both measures. Interestingly, columns 3, 5 and 6 show this income effect being stronger under negative shocks, low debt and relatively open economies. While column three does not provide clear evidence of our buffer effect for neither stock of reserves nor change in reserves, column for on table 8 shows that

\footnotetext{
${ }^{6}$ This asymmetry may reflect country's concern that losing reserves during a downturn might increase its vulnerability to deleveraging and sudden stops. In addition, deflationary shocks (drops in commodity prices, collapsing export demands, etc.) may mitigate concerns of the inflationary consequences associated with depreciation, increasing the perceived gain of depreciation as a form of demand switching policy, improving the competitiveness of a country.
} 
accumulation and de-accumulation of reserves buffers the transmission of positive and negative CTOT shocks to output. Results from the IRF in this last specification portray a slightly different picture. Figure $3 \mathrm{~A}$ shows a clear role of active reserve management on stabilizing output volatility under positive shocks. Increasing the rate at which the country accumulates reserves from 1 percent to 3 percent of GDP helps decrease the volatility of the output after positive CTOT shocks by 26 percent over the following two years. On the opposite end, figure 3B shows that while de-accumulation of reserves seems to help decrease the effect of negative CTOT shocks into output on impact, this policy seems to have an insignificant role buffering the CTOT shock in the following periods.

As mentioned above, an important extension to our previous work with reserves consists in looking at the effects of managing foreign assets in the form of SWF balances. The SWF included in this study follow a set of fiscal rules that allow countries to manage windfalls from increases in the international prices of the exporting commodities. Tables 9 and 10 report the estimated coefficients for our basic model using the balance of SWF as our proxy for access to international liquidity. While the most significant effects are obtained in the study of different periods (see table 11 and text below), there are some interesting results captured by tables 9 and 10; first, in contrast to what we observed with reserves, SWF seem to act as an important buffer to REER under fixed exchange rate regimes and relatively close economies. Additionally, SWF buffers the effect on Output growth for relatively high debt observations. Interestingly, holding large SWF balances seem to increase, instead of decrease, the effects of CTOT shocks on real output during negative shocks and under fixed exchange regimes. As explained in the next section of the paper, this effect may reflect the period of SWF accumulation just before the Great Recession. Once we divide the sample in different periods of interest, we observe that SWF start buffering the CTOT effects on Output during and after the Great Recession, replacing reserves on this role.

\section{What were the effects of the Great Recession on our buffer story?}

One of the more important questions in this project is to examine the effects of the Great Recession. In this section we apply our basic model of liquidity buffer to four distinct periods in time, each with a special economic significance for LATAM region. Our first sample period covers data ranging from the beginning of 1980s to the end of 2002. These are turbulent times in Latin America. Just 
to cover a few of the major economic crises we have the debt crisis in 1982 that led to the lost decade, the Tequila crises in 1994-95 and the Argentinian crises in 2001-02. Many Latin American economies were plagued by hyperinflation during this period and carried high output and real exchange rate volatility. From Table 11 we see how the buffer effect, measured from either the stock of reserves or its active management, is strongest during this period. To further this point we compare the IRFs from holding $5 \%$ or $15 \%$ of GDP in reserves in Figure 4A. From this figure we observe a very large decrease in REER volatility, specifically volatility in the IRF drops by almost $45 \%$. We could argue that in the absence of credible inflation rules or other countercyclical fiscal policies, liquidity (through international reserves) management was one of the strongest tools for emerging LATAM economies to lower inherited macroeconomic volatility. These two decades are the poster child for our international liquidity buffer story.

The second period of interest runs from 2003 to 2007. Due to the relatively low macroeconomic volatility in many emerging regions, this period it's commonly dubbed as the end of the Great Moderation (GM). During this time the relationship between CTOT shocks and real appreciation remains positive but we lose some significance in our regressions. As shown by the IRFs in Figure 4B, the buffer effect of reserves remained strong, delaying any reaction of REER to changes in CTOT by more than a year. The Great Recession (GR) brings a change in the previously found empirical regularities. In short, the link between CTOT and REER seems to decrease substantially and any role for reserves to buffer the shocks disappears. Figure 4C clearly represents this change. Finally, we observe the relationship between CTOT and REER and our buffer story reappear during the years following the GR (2010 to 2013). Nevertheless, neither the link between CTOT and REER nor the buffer effect of reserves return to the levels observed before the crises.

Interestingly, while the stock of reserves fails to smooth the transmission of CTOT shocks to REER during the Great Recession, we observe SWF stepping up as a potential substitute to traditional reserve assets. Figure 5A and 5B show how moving the stock of SWF assets from 1 to 3 percent of GDP decreased volatility in the GR and the post GR period by 16 and 32 percent respectively. Column 6 of table 11 shows that SWF were also effective smoothing the transmission of CTOT shocks to real output growth during the GR and the post GR periods.

\section{International Reserves versus Sovereign Wealth Funds: Substitutes or Complements?}


Results in the previous section show that during the Great Recession (2007-9) and the following years, SWF seemed to inherit the role of buffering LATAM economies against real external shocks previously assigned to international reserves. In this section, we want to look closely at the relationship between the two different tools of liquidity management over last two decades. In order to understand the short run relationship between movements in the stock of reserves and movements in the balance of SWF we build two error correction models as follows:

$$
\begin{aligned}
\Delta R E S_{i t}=\alpha_{i}+ & \delta_{t}+\beta_{1} \Delta S W F_{i t}+\sum_{k=1}^{3} \beta_{k+1} \Delta S W F_{i t-k}+\sum_{k=1}^{3} \theta_{k} \Delta R E S_{i t-k}+\gamma_{1} \Delta S W F_{i t-1}+\gamma_{2} \Delta R E S_{i t-1} \\
& +\varepsilon_{i t}
\end{aligned}
$$

$$
\begin{aligned}
\Delta S W F_{i t}=\alpha_{i} & +\delta_{t}+\beta_{1} \Delta R E S_{i t}+\sum_{k=1}^{3} \beta_{k+1} \Delta R E S_{i t-k}+\sum_{k=1}^{3} \theta_{k} \Delta S W F_{i t-k}+\gamma_{1} \Delta S W F_{i t-1}+\gamma_{2} \Delta R E S_{i t-1} \\
& +\mu_{i t}
\end{aligned}
$$

where RES and SWF represents the stock of reserves and the total balance of SWF as a ratios of GDP. The results of running these regressions for the full sample of countries and years, starting from 2003 (where most SWF start to arise) and restricting the sample to countries that had Stabilization SWFs are shown in Table 12. Interestingly, we observe that an increase on assets in SWFs seems to be associated to a significant decrease of International reserves on impact in all specifications. These negative correlations range from .32 to .54 percent of GDP decrease in reserves in the face of a 1 percent of GDP increase in SWF balances. Moreover, looking at the three lags in our specification, we find joint significance for all betas at 99 percent confidence level. The same cannot be said when we look at the SWF equation; we find that changes in reserves are not associated to significant changes in SWF.

Looking at the impulse responses over a two-year time horizon in figures 6 and 7, gives us an even clearer picture. In figure 6A we observe that a 1 percent of GDP increase in SWF balances carries a negative and significant (at 95\% confidence level) accumulated effect on reserves of approximately 34 percent of GDP on impact and a maximum effect of .56 percent after one quarter. Again, looking at figure $6 \mathrm{~B}$, there seems to be no reaction on SWF after changes on reserves. Figures 7A and 7B show similar results if we consider only countries with active SWFs over our sample (Chile, Colombia, 
Ecuador, Mexico and Venezuela). This evidence seems to reaffirm our substitution story. The emergence of SWF during the 2000's seemed to provide a valid substitute tool for active liquidity management policies in LATAM countries. While further analysis of these interesting policy interactions seems warranted, we leave a more in-depth analysis for future work.

\section{Liquidity management and Inflation Targeting}

A key monetary policy change to explain macroeconomic performance in Latin American over the last decade and a half is the move by half of our sample to inflation targeting. In this section we investigate how target rules affected the ability or willingness of LATAM economies to use international liquidity to reduce the macroeconomic volatility inherited from external shocks.

In order to understand the policy goals of LATAM economies we start by setting up an augmented Taylor rule were we fit the domestic policy rate to a measure of the output gap, CPI inflation and real appreciation. In an alternative specification we use non-linear dummy approach to separate the sample between IT and Non-IT countries. Table 13 reports the estimated coefficients. Interpreting these coefficients as the weights across macroeconomic policy goals, we observe that output gaps seem to be the most important component for setting up the policy rate. While inflation seems to gain importance for IT countries, the weight in the Taylor rule seems relatively small. Importantly for our study, Non-IT countries seem to switch from a REER target to an inflation target when committing to an IT rule. This means, potentially, that liquidity management is not-longer used towards the stabilization of REER under an IT rule. To investigate this possibility, we adjust our basic specification to account for IT countries and show the results in table 14. Figure 8 builds the IRF for Non-IT vs. IT countries. As expected, liquidity management seems to be efficient only across Non-IT countries reducing CTOT volatility by 35 percent over two years in the IRF. The relationship between CTOT and REER becomes more chaotic and the buffer story disappears among IT countries. Based on columns 2 and 4 from table 14, SWF seem to provide IT countries with an alternative form of liquidity management against foreign shocks when traditional reserves are committed to other macroeconomic goals. This is true for both REER and output growth stabilization. 


\section{Conclusion}

Our paper documents and validates the growing importance of liquidity management for commodity exporting countries, mitigating the transmission from terms of trade shocks to the real exchange rate, stabilizing thereby the domestic economy. We find evidence that SWFs may provide another margin of stabilization, and this role may be of greater relevance for IT countries, and in periods of heightened volatility. This division of labor is consistent with Tinbergen rule in policy design: to reach $n$ targets, one may use $n$ independent instruments. International reserves are useful in dealing with balance sheet exposure, aiming at short and intermediate run stabilization objectives. Yet, hoarding international reserves is not a panacea, as the opportunity cost of reserves imposes a fiscal cost, and hoarding reserves may require sterilization to mitigate their inflationary consequences. Thereby, an inflation targeting regime may relegate the goal of real exchange rate stabilization to a sovereign wealth fund. Such a fund may have greater risk tolerance, and its accumulation impacts directly the fiscal stance and the real exchange rate. ${ }^{7}$ Remarkably, the buffering roles of reserves and SWFs does not need East Asian levels of hoarding - they are operative in LATAM at relatively modest levels of reserves/GDP and SWF/GDP.

\footnotetext{
${ }^{7}$ This assignment is consistent with the view that IR has comparative advantage in dealing with balance sheet exposure, SWF with longer term saving, and fiscal stabilization.
} 


\section{References}

Aizenman Joshua, Sebastian Edwards and Daniel Riera-Crichton. 2012. “Adjustment patterns to commodity terms of trade shocks: the role of exchange rate and international reserves policies," Journal of International Money and Finance, 2012, 31, 8, pp 1990-2016.

Aizenman Joshua and Daniel Riera-Crichton. 2008. "Real exchange rate and international reserves in the era of growing financial and trade integration," Review of Economics and Statistics, 90: 4, pp. 812-815.

Aizenman Joshua and Reuven Glick. 2009. "Sovereign Wealth Funds: Stylized Facts about their Determinants and Governance," International Finance, vol. 12(3), pages 351-386, December. (2010) "Asset Class Diversification and Delegation of Responsibilities between a Central Bank and Sovereign Wealth Fund", NBER Working paper 16392, forthcoming, the International Journal of Central Banking.

Aizenman Joshua, Michael Hutchison and Ilan Noy. "Inflation Targeting and Real Exchange Rates in Emerging Markets," 2011. World Development, 39:5, pp. 712-724.

Céspedes Luis Felipe and Andrés Velasco. 2012. "Macroeconomic Performance During Commodity Price Booms and Busts," IMF Economic Review 60, pp 570-599.

2014. "Was this time different?: Fiscal policy in commodity republics," Journal of Development Economics, Volume 106, January, Pages 92-106.

Céspedes, Luis Felipe, Roberto Chang, and Andrés Velasco. 2012. "Is Inflation Targeting Still On Target?” NBER Working Paper No. 18570.

Frankel, Jeffrey. 2011. "A Solution to Fiscal Procyclicality: the Structural Budget Institutions Pioneered by Chile," Journal Economía Chilena (The Chilean Economy), Central Bank of Chile, vol. 14 (2), pp 39-78, August.

Frankel, Jeffrey A. \& Vegh, Carlos A. \& Vuletin, Guillermo. 2013. "On graduation from fiscal procyclicality," Journal of Development Economics, vol. 100(1), pp 32-47.

Jorda, Oscar, 2005. "Estimation and inference of impulse responses by local projections." American Economic Review 95 (1), 161-182.

Mishkin Frederic S. and Klaus Schmidt-Hebbel. 2007. "Does Inflation Targeting Make a Difference?" NBER Working Paper No. 12876.

Stock, James, and Mark Watson, 2007. “Why has U.S. inflation become harder to forecast?”Journal of Money, Banking and Credit 39, 1-33. 


\section{Appendix A Data Definition and Sources}

CTOT: Commodity terms-of-trade data set was constructed following Ricci et. al (2008):

$$
C T O T_{i}=\prod_{j}\left(P_{j} / M U V\right)^{X_{j}^{i}} / \prod_{j}\left(P_{j} / M U V\right)^{M_{j}^{i}},
$$

where $P j$ is the price index for six commodity categories (food, fuels, agricultural raw materials, metals, gold, and beverages), and $\left(\mathrm{X}_{j}^{i}, M_{j}^{i}\right)$ are the average shares of commodity $j$ in country $i^{\text {‘ }}$ s exports and imports over GDP for the period 1980 through 2012, respectively. Commodity prices are deflated by the manufacturing unit value index (MUV). Sources: UN ComTrade, IMF, World Bank

TCTOT: Transitory CTOT shocks are defined as the log deviations of actual CTOT from long run values calculated through a HP filter.

REER: Real effective exchange rate is defined a trade based weighted average of nominal bilateral exchange rates deflated by the relative consumer price indexes. An increase in REER represents a real appreciation of the domestic currency. DREER represents the log change in REER. Sources: DataStream, IMF

RES: The stock of foreign reserve assets is measured in millions of us dollars and deflated by the five year moving average of the interpolated annual nominal Gross Domestic Product. DRES represents the change in the reserves to GDP ratio. Global Financial Data, IMF

ECMREER: Error correction REER is the log difference between current REER and long term REER. In order to compute the equilibrium/long-run REER, we use a co-integrating approach. The methodology calls for a series of co-integrating regressors. Following Edwards (1989), Montiel (1999) and others, we estimate the following equation:

$$
\operatorname{Ln}(\text { REER })_{t}=\alpha+\mathrm{B}\left[\begin{array}{c}
\text { Ln }(\text { CTOT })_{t} \\
\text { GOV }_{t} \\
\text { TradeOpen }_{t} \\
\text { USINF }_{t} \\
\text { TimeTrend }_{t} \\
\text { IntSpread }_{t}
\end{array}\right]+\varepsilon_{t i}
$$


The term CTOT is commodity terms of trade, Gov represents the share of Government Expenditures over GDP, TradeOpen is a measure of Trade Openness (Exports plus Imports over GDP), USINF is a measure of inflation in the US based on the US CPI and represents world inflation and IntSpread is the domestic market reference interest rate spread from the 3-month US T-Bill. Once we obtain the coefficients from equation (A-1), we use the HP filter to find the long run values of the fundamentals, we then use these values, jointly with the estimated coefficients, to generate what we refer to as the Long Run REER (LRREER). Sources: World Bank, Penn Tables.

RGDP: Real GDP is taking at a true quarterly frequency from different sources. The table below shows the source and data availability. DRGDP represents the log change in RGDP.

\begin{tabular}{lll}
\hline Country & Source & Data \\
\hline Argentina & Inter American Development Bank & $1990 Q 1$ \\
Bolivia & Inter American Development Bank & $1990 Q 1$ \\
Brazil & Inter American Development Bank & $1990 Q 1$ \\
Chile & Global Financial Data & $1991 Q 1$ \\
Colombia & Global Financial Data & $1994 Q 1$ \\
Costa Rica & FRED & $1991 Q 1$ \\
Ecuador & Global Financial Data & $1992 Q 1$ \\
Mexico & FRED & $1981 Q 1$ \\
Paraguay & Inter American Development Bank & $1994 Q 1$ \\
Peru & Global Financial Data & $1980 Q 1$ \\
Uruguay & Inter American Development Bank & $1997 Q 1$ \\
Venezuela & Inter American Development Bank & $1993 Q 1$ \\
\hline
\end{tabular}

FIXED vs FLEX FOREX DUMMIES: Using the de facto exchange rate regime classification of Ilzetzki, Reinhart, and Rogoff (2008), we define, a nominal fixed exchange regime as one where the country either has no legal tender, a hard peg, a crawling peg, and de facto or pre-announced bands or crawling bands with margins of no larger than $+/-2 \%$. All other arrangements are classified as nominal flexible regimes (we exclude episodes of "Free Falling" from the sample of the regression). Sources: TRADE OPEN VS. CLOSE DUMMIES: Based on the literature we consider a country to be "Open" if our ratio (EX+IM)/GDP is larger than $40 \%$ and close if its lower than $40 \%$.

HIGH VS. LOW DEBT DUMMIES: We consider High Government Debt any amount over 45 percent of GDP. 
IT: Inflation targeting is a dummy with value 1 if the country is officially targeting inflation and zero otherwise. The table 3 shows the IT country/periods. Target bands and transition periods.

SWF: Balance of Sovereign Wealth Fund balances obtained from commodity revenues and dedicated to macroeconomic stabilization. SWF is measured in millions of US dollars and is deflated by the five year moving average of the interpolated annual nominal GDP. DSWF represents the change in SWF balance over GDP ratio. See table 2 for the summary of the funds.

Central Bank Policy Rate: Reference interest rate used by the central bank to conduct monetary policy. Below are the reference rates used and data availability.

\begin{tabular}{lll}
\hline Country & Policy Rate & Data Availability \\
\hline Argentina & Argentina 15-day Loans to Financial Institutions & $1980-2013$ \\
Bolivia & Bolivia Central Bank Discount Rate & $1980-2014$ \\
Brazil & Brazil Deposit Rate Over SELIC & $1980-2015$ \\
Chile & Chile Monetary Policy Rate & $1990-2016$ \\
Colombia & Colombia Bank of the Republic Discount Rate & $1980-2017$ \\
Costa Rica & Costa Rica Central Bank Deposit Rate & $1991-2018$ \\
Ecuador & Ecuador Central Bank Discount Rate & $1980-2019$ \\
Mexico & Mexico 28 Day Interbank Rate (TIIE) & $1980-2020$ \\
Paraguay & Paraguay Interbank Rate & $1990-2022$ \\
Peru & Central Bank of Peru Discount Rate & $1980-2023$ \\
Uruguay & Uruguay Central Bank Discount Rate & $1981-2024$ \\
Venezuela & Venezuela Central Bank Discount Rate & $1980-2025$ \\
\hline
\end{tabular}
Sources: Global Financial Data, DataStream. 


\section{Glossary of Terms for Tables in the Appendix}

\begin{tabular}{|ll|}
\hline REER: & Real Effective Exchange Rate. An increase implies real appreciation \\
\hline DREER & 1 period log change in REER \\
\hline RES: & Stock of Reserves over GDP \\
\hline DRES: & 1 period change in the reserves over GDP \\
\hline TCTOT: & $\begin{array}{l}\text { Transitory CTOT shocks are defined as the log difference between CTOT and a long } \\
\text { run measure of CTOT obtained from applying the HP filter to the original series. }\end{array}$ \\
\hline RGDP: & Real Gross Domestic Product in national currency and seasonally adjusted \\
\hline DRGDP: & One period log change of RGDP \\
\hline X and Y: & $\begin{array}{l}\text { We use "X" and "Y" to proxy for the different variables used in different } \\
\text { specifications across the same table. See the top row of each column to see what } \\
\text { these variables are in each specification }\end{array}$ \\
\hline ECT: & $\begin{array}{l}\text { The Error Correction Term is the distance of the variable to the long run value. See } \\
\text { appendix for the description of the REER long run value. For Output Growth, we take } \\
\text { log deviations from the smoothed series obtained from applying the HP filter to the } \\
\text { original series. }\end{array}$ \\
\hline SWF: & Balance of the Macro-Stability Sovereign Wealth Fund as a ratio of GDP \\
\hline DSWF: & 1 period change in the balance of SWF over GDP \\
\hline GM: & Great Moderation Dummy: 1 if between 2003Q1-2007Q4, 0 otherwise \\
\hline GR: & Great Recession Dummy: 1 if between 2008Q1-2009Q4, 0 otherwise \\
\hline AGR: & After Great Recession Dummy: 1 if between 2010Q1-2013Q4, 0 otherwise \\
\hline INF: & Inflation measured as the log difference of the consumption price index \\
\hline IT: & Inflation Target Dummy. 1 if the country has an Inflation Target, 0 otherwise. \\
\hline
\end{tabular}




\section{Appendix B Tables and Figures}

Table 1: Real Output Growth and Real Exchange Rate in LAC 7

\begin{tabular}{lcccc}
\hline & $\begin{array}{c}\text { Pre-GM } \\
1990-2003\end{array}$ & $\begin{array}{c}\text { Great Moderation } \\
2003-2007\end{array}$ & $\begin{array}{c}\text { Great Recession } \\
\text { 2008-2019 }\end{array}$ & $\begin{array}{c}\text { Post-GR } \\
2010-2013\end{array}$ \\
\hline REAL OUTPUT GROWTH & & & & \\
\hline Annual Averages & 3.01 & 5.71 & 2.04 & 5.12 \\
STDEV & 2.43 & 1.87 & 4.12 & 0.91 \\
\hline REAL APPRECIATION VS. THE US\$ & & & 1.56 & 3.4 \\
\hline Annual Averages & -1.21 & 5.61 & 7.83 & 3.21 \\
STDEV & 7.61 & 3.24 & & \\
\hline Annual data was taken from IADB Macro Watch. LAC-7 includes Argentina, Brazil, Chile, Colombia, Mexico, Peru and Venezuela
\end{tabular}

Table 2: Commodity based Stabilization SWF in LATAM

\begin{tabular}{|c|c|c|c|c|}
\hline Country & Fund & Coverage & Commodity & Source \\
\hline Chile & $\begin{array}{l}\text { Fondo de Estabilización de los } \\
\text { Ingresos del Cobre (Copper Fund) }\end{array}$ & 1987-2006 & Copper & Tesoreria General de la Republica \\
\hline Chile & FEES & $2007-2013$ & Copper & Hacienda Publica de Chile \\
\hline Colombia & $\begin{array}{l}\text { Fondo de Ahorro y Estabilización } \\
\text { Petrolera }\end{array}$ & $1996-2013$ & Oil & $\begin{array}{l}\text { Ministerio de Hacienda y Crédito } \\
\text { Público }\end{array}$ \\
\hline Ecuador & FEP & 2000-2007 & Oil & Ministry of Economy \\
\hline Ecuador & FEIREP & 2002-2004 & Oil & Ministry of Economy \\
\hline Ecuador & CEREPS & 2005-2007 & Oil & Ministry of Economy \\
\hline Ecuador & FAC & 2005-2007 & Oil & Ministry of Economy \\
\hline Ecuador & FEISEH & 2006-2007 & Oil & Ministry of Economy \\
\hline Mexico & $\begin{array}{l}\text { Fondo de estabilizacion de ingresos } \\
\text { petroleros (FEP) }\end{array}$ & $2000-2013$ & Oil & $\begin{array}{l}\text { Secretaría de Hacienda y Crédito } \\
\text { Público }\end{array}$ \\
\hline Peru & Fondo de Estabilización Fiscal & $2000-2013$ & Oil and Gas & $\begin{array}{l}\text { Ministerio de Economía y Finanzas } \\
\text { del Perú }\end{array}$ \\
\hline Venezuela & $\begin{array}{l}\text { Fondo de Estabilidad } \\
\text { Macroeconomica }\end{array}$ & $1999-2013$ & Oil & Banco Central de Venezuela \\
\hline
\end{tabular}


Table 3: Inflation Targets in Latin America

\begin{tabular}{lccc}
\hline & $\begin{array}{c}\text { Converging } \\
\text { target period }\end{array}$ & Stationarity-Target Period & $\begin{array}{c}\text { 2005 inflation } \\
\text { target level (\%) }\end{array}$ \\
\hline Brazil & $1999: 1-2004: 4$ & $2004-$ & $4.5(+/-2.5)$ \\
Chile & $1991: 1-2000: 4$ & $2001-$ & $2-4$ \\
Colombia & $1999: 1-2004: 4$ & $2004-$ & $5(+/-0.5)$ \\
Mexico & $1999: 1-2002: 4$ & $2004-$ & $3(+/-1)$ \\
Peru & $1994: 1-2001: 4$ & $2002-$ & $2.5(+/-1)$ \\
Uruguay & $2002: 2-2003: 4$ & $2004-$ & N.A. \\
\hline
\end{tabular}

Table 4: Descriptive statistics.

\begin{tabular}{|c|c|c|c|c|c|}
\hline ALL OBSERVATIONS & Obs & Mean & Std. Dev. & Min & Max \\
\hline DREER & 1576 & -0.001492 & 0.088289 & -1.936263 & 0.6924086 \\
\hline ECM REER & 1516 & -0.0015106 & 0.1273096 & -0.5987437 & 1.365942 \\
\hline DRGDP & 1083 & 0.0088561 & 0.0203312 & -0.1385784 & 0.1955137 \\
\hline ECM RGDP & 1093 & 0.0005406 & 0.0294761 & -0.28123 & 0.1574097 \\
\hline тстот & 1632 & $3.94 \mathrm{E}-11$ & 0.0144423 & -0.1111243 & 0.1186696 \\
\hline RES OVER GDP & 1632 & 0.097068 & 0.0651493 & 0.0053772 & 0.4217554 \\
\hline SWF OVER GDP & 1632 & 0.0028891 & 0.010467 & 0 & 0.1132718 \\
\hline DRES & 1620 & 0.0007563 & 0.0116144 & -0.086744 & 0.0801628 \\
\hline DSWF & 1620 & 0.0000591 & 0.0017731 & -0.0247848 & 0.0261156 \\
\hline IT DUMMY & 1632 & 0.2444853 & 0.4299133 & 0 & 1 \\
\hline FLEX REGIME & 1138 & 0.4841828 & 0.4999695 & 0 & 1 \\
\hline FIXED REGIME & 1138 & 0.5158172 & 0.4999695 & 0 & 1 \\
\hline HI DEBT & 1632 & 0.471201 & 0.4993229 & 0 & 1 \\
\hline LOW DEBT & 1632 & 0.528799 & 0.4993229 & 0 & 1 \\
\hline TRADE OPEN & 1632 & 0.4920343 & 0.5000898 & 0 & 1 \\
\hline TRADE CLOSE & 1632 & 0.5079657 & 0.5000898 & 0 & 1 \\
\hline
\end{tabular}


TABLE 5: Buffer Effect of the Stock of Reserves on REER

\begin{tabular}{|c|c|c|c|c|c|c|}
\hline MODEL & Basic Model & $\begin{array}{l}\text { Stock of } \\
\text { Reserves }\end{array}$ & $\begin{array}{c}\text { Pos (X) } \\
\text { vs Neg (Y) } \\
\text { СTOT Shock }\end{array}$ & $\begin{array}{c}\text { Flex }(X) \\
\text { vs Fixed }(Y) \\
\text { Forex } \\
\end{array}$ & $\begin{array}{c}\text { Hi }(X) \\
\text { vs Low }(Y) \\
\text { Debt } \\
\end{array}$ & $\begin{array}{c}\text { Open (X) } \\
\text { vs Close (Y) } \\
\text { Trade } \\
\end{array}$ \\
\hline VARIABLES & DREER & DREER & DREER & DREER & DREER & DREER \\
\hline DREER (t-1) & {$[0.060]$} & {$[0.060]$} & {$[0.061]$} & {$[0.044]^{* * *}$} & {$[0.060]$} & [0.059] \\
\hline \multirow[t]{2}{*}{ ECT REER (t-1) } & -0.2356 & -0.2368 & -0.2390 & -0.1459 & -0.2369 & -0.2435 \\
\hline & {$[0.066]^{* * *}$} & {$[0.067]^{* * *}$} & {$[0.067]^{* * *}$} & {$[0.017]^{* * *}$} & {$[0.067]^{* * *}$} & {$[0.071]^{* * *}$} \\
\hline \multirow[t]{2}{*}{ TCTOT * RES (t-1) } & & -2.5802 & & & & \\
\hline & & {$[0.705]^{* * *}$} & & & & \\
\hline \multirow[t]{2}{*}{ тстот * X (t-1) } & & & 1.8765 & 1.3254 & 0.8367 & 0.2177 \\
\hline & & & {$[0.459]^{* * *}$} & {$[0.624]^{*}$} & {$[0.318]^{* *}$} & [0.164] \\
\hline ТСтОт * Y (t-1) & & & -0.0397 & 0.2526 & 0.7031 & 2.1394 \\
\hline TCTOT * RES * Y (t-1) & & & [2.695] & [0.605] & [1.714] & {$[3.032]^{* *}$} \\
\hline \multirow[t]{2}{*}{ RES (t-1) } & 0.1126 & 0.1100 & 0.1730 & 0.0766 & 0.1093 & 0.1122 \\
\hline & {$[0.043]^{* *}$} & {$[0.042]^{* *}$} & {$[0.065]^{* *}$} & {$[0.022]^{* * *}$} & {$[0.041]^{* *}$} & {$[0.045]^{* *}$} \\
\hline Observations & 1,496 & 1,496 & 1,496 & 1,082 & 1,496 & 1,496 \\
\hline R-squared & 0.113 & 0.114 & 0.117 & 0.153 & 0.114 & 0.121 \\
\hline Number of country & 12 & 12 & 12 & 12 & 12 & 12 \\
\hline
\end{tabular}

Robust standard errors in brackets. ${ }^{* * *} p<0.01,{ }^{* *} p<0.05, * p<0.1$.

DREER is the real exchange rate appreciation. TCTOT represents transitory commodity terms of trade shocks. RES are the stock of international reserves over GDP. DRES is the change in RES. Quarterly observations from 1980Q1 to 2013Q4. All observations available were used 
TABLE 6: Buffer Effect of Active Change of Reserves on REER

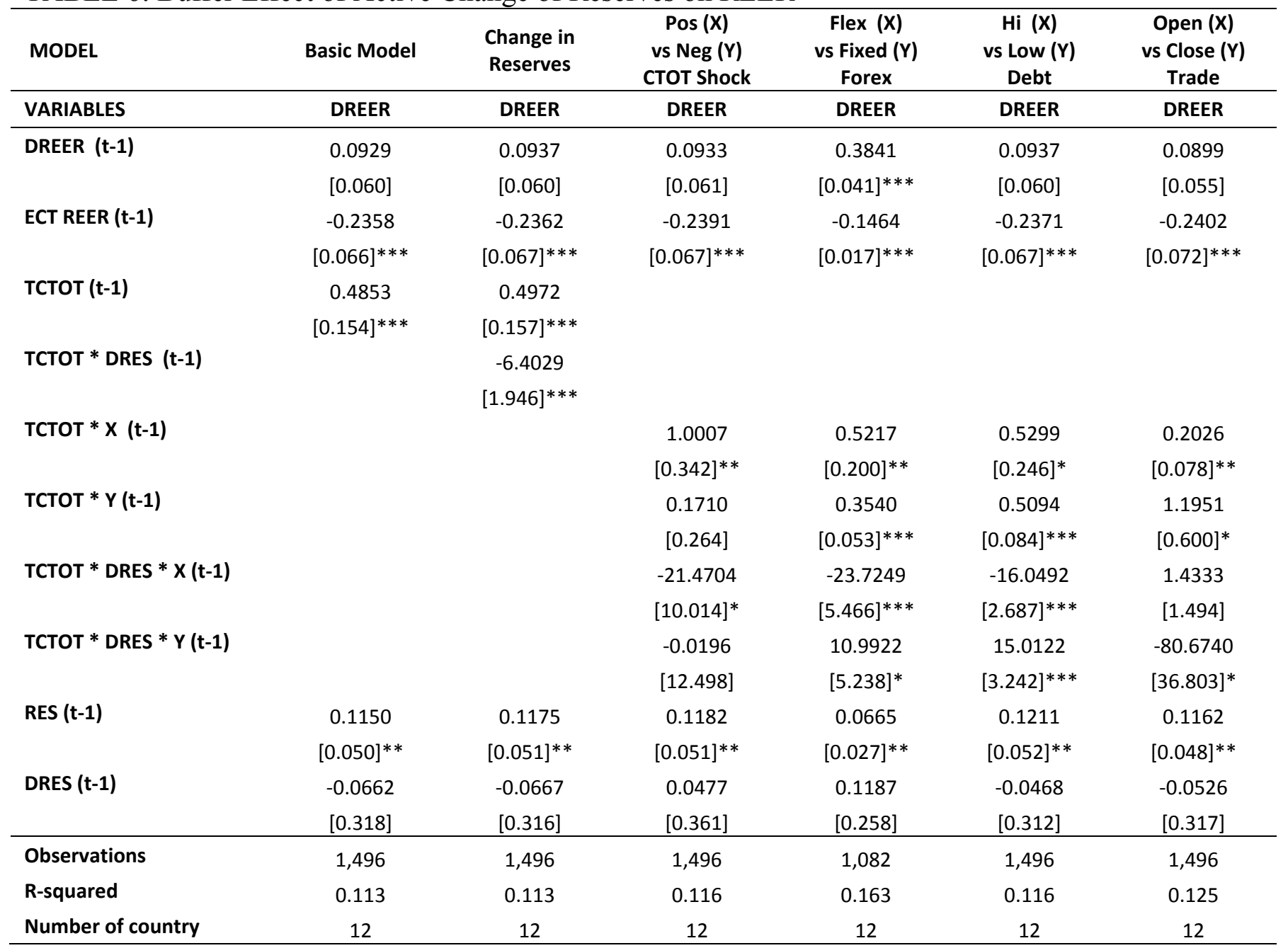

Robust standard errors in brackets. $* * * p<0.01, * * p<0.05, * p<0.1$.

DREER is the real exchange rate appreciation. TCTOT represents transitory commodity terms of trade shocks. RES are the stock of international reserves over GDP. DRES is the change in RES. Quarterly observations from $1980 \mathrm{Q} 1$ to $2013 \mathrm{Q} 4$. All observations available were used 
TABLE 7: Buffer Effect of the Stock of Reserves on Output Growth

\begin{tabular}{|c|c|c|c|c|c|c|}
\hline MODEL & Basic Model & $\begin{array}{l}\text { Stock of } \\
\text { Reserves }\end{array}$ & $\begin{array}{c}\text { Pos (X) } \\
\text { vs Neg (Y) } \\
\text { СTOT Shock }\end{array}$ & $\begin{array}{c}\text { Flex }(X) \\
\text { vs Fixed }(Y) \\
\text { Forex }\end{array}$ & $\begin{array}{c}\text { Hi }(X) \\
\text { vs Low }(Y) \\
\text { Debt }\end{array}$ & $\begin{array}{c}\text { Open }(X) \\
\text { vs Close }(Y) \\
\text { Trade }\end{array}$ \\
\hline VARIABLES & DRGDP & DRGDP & DRGDP & DRGDP & DRGDP & DRGDP \\
\hline \multirow[t]{2}{*}{ DRGDP (t-1) } & 0.1672 & 0.1664 & 0.1637 & 0.1692 & 0.1700 & 0.1670 \\
\hline & {$[0.053]^{* * *}$} & {$[0.053]^{* * *}$} & {$[0.054]^{* *}$} & {$[0.056]^{* *}$} & {$[0.052]^{* * *}$} & {$[0.054]^{* *}$} \\
\hline ECT RGDP (t-1) & -0.2690 & -0.2686 & -0.2653 & -0.3265 & -0.2753 & -0.2698 \\
\hline \multirow[t]{2}{*}{ тстот (t-1) } & 0.2138 & 0.2639 & & & & \\
\hline & {$[0.061]^{* * *}$} & {$[0.075]^{* * *}$} & & & & \\
\hline \multirow[t]{2}{*}{ TCTOT * RES (t-1) } & & -0.4139 & & & & \\
\hline & & {$[0.376]$} & & & & \\
\hline Tстот * Y (t-1) & & & {$[0.092]^{* * *}$} & {$[0.038]^{* * *}$} & {$[0.078]^{* * *}$} & {$[0.235]$} \\
\hline \multirow[t]{2}{*}{ TCTOT * RES * X (t-1) } & & & -0.3937 & -0.0284 & -0.1399 & -0.6093 \\
\hline & & & [0.537] & [2.127] & [0.399] & {$[0.254]^{* *}$} \\
\hline \multirow[t]{2}{*}{ TCTOT * RES * Y (t-1) } & & & -0.5547 & -0.5785 & 0.2957 & 0.1523 \\
\hline & & & {$[0.474]$} & {$[0.301]^{*}$} & [0.809] & {$[2.075]$} \\
\hline \multirow[t]{2}{*}{ RES (t-1) } & 0.0190 & 0.0182 & 0.0176 & 0.0112 & 0.0182 & 0.0197 \\
\hline & {$[0.009]^{*}$} & {$[0.009]^{*}$} & {$[0.011]$} & [0.011] & {$[0.009]^{*}$} & {$[0.010]^{*}$} \\
\hline Observations & 1,073 & 1,073 & 1,073 & 842 & 1,073 & 1,073 \\
\hline R-squared & 0.155 & 0.155 & 0.156 & 0.191 & 0.160 & 0.157 \\
\hline
\end{tabular}


TABLE 8: Buffer Effect of Active Change of Reserves on Output Growth

\begin{tabular}{|c|c|c|c|c|c|c|}
\hline MODEL & Basic Model & $\begin{array}{l}\text { Change in } \\
\text { Reserves }\end{array}$ & $\begin{array}{c}\text { Pos (X) } \\
\text { vs Neg (Y) } \\
\text { СTOT Shock }\end{array}$ & $\begin{array}{c}\text { Flex }(\mathrm{X}) \\
\text { vs Fixed }(\mathrm{Y}) \\
\text { Forex }\end{array}$ & $\begin{array}{c}\text { Hi }(\mathrm{X}) \\
\text { vs Low (Y) } \\
\text { Debt }\end{array}$ & $\begin{array}{c}\text { Open }(\mathrm{X}) \\
\text { vs Close }(\mathrm{Y}) \\
\text { Trade } \\
\end{array}$ \\
\hline VARIABLES & DRGDP & DRGDP & DRGDP & DRGDP & DRGDP & DRGDP \\
\hline \multirow[t]{2}{*}{ DRGDP (t-1) } & 0.1670 & 0.1676 & 0.1704 & 0.1696 & 0.1729 & 0.1691 \\
\hline & {$[0.053]^{* * *}$} & {$[0.053]^{* * *}$} & {$[0.052]^{* * *}$} & {$[0.056]^{* *}$} & {$[0.052]^{* * *}$} & {$[0.054]^{* * *}$} \\
\hline \multirow[t]{2}{*}{ ECT RGDP (t-1) } & -0.2685 & -0.2689 & -0.2701 & -0.3266 & -0.2762 & -0.2693 \\
\hline & {$[0.045]^{* * *}$} & {$[0.045]^{* * *}$} & {$[0.045]^{* * *}$} & {$[0.023]^{* * *}$} & {$[0.046]^{* * *}$} & {$[0.044]^{* * *}$} \\
\hline \multirow[t]{2}{*}{ ТСТОТ (t-1) } & 0.2070 & 0.2072 & & & & \\
\hline & {$[0.066]^{* * *}$} & {$[0.067]^{* *}$} & & & & \\
\hline \multirow[t]{2}{*}{ TCTOT * DRES (t-1) } & & 0.5048 & & & & \\
\hline & & [1.864] & & & & \\
\hline \multirow[t]{2}{*}{ тСтот * X (t-1) } & & & 0.1842 & 0.2400 & 0.0745 & 0.2272 \\
\hline & & & {$[0.058]^{* * *}$} & {$[0.068]^{* * *}$} & {$[0.086]$} & {$[0.056]^{* * *}$} \\
\hline \multirow[t]{2}{*}{ ТСТОТ * Y (t-1) } & & & 0.3133 & 0.2383 & 0.3080 & 0.0448 \\
\hline & & & {$[0.090]^{* * *}$} & {$[0.065]^{* * *}$} & {$[0.032]^{* * *}$} & [0.207] \\
\hline \multirow[t]{2}{*}{ TCTOT * DRES * X (t-1) } & & & -10.3490 & -0.4778 & -3.1602 & 0.9845 \\
\hline & & & {$[2.267]^{* * *}$} & [6.058] & [1.807] & [1.680] \\
\hline \multirow[t]{2}{*}{ TCTOT * DRES * Y (t-1) } & & & 7.5174 & 0.3416 & 3.7605 & -9.8432 \\
\hline & & & {$[1.358]^{* * *}$} & {$[2.023]$} & {$[1.136]^{* * *}$} & [20.360] \\
\hline \multirow[t]{2}{*}{ RES (t-1) } & 0.0171 & 0.0169 & 0.0185 & 0.0122 & 0.0177 & 0.0179 \\
\hline & {$[0.008]^{*}$} & {$[0.007]^{* *}$} & {$[0.007]^{* *}$} & {$[0.011]$} & {$[0.008]^{* *}$} & {$[0.009]^{*}$} \\
\hline \multirow[t]{2}{*}{ DRES (t-1) } & 0.0480 & 0.0489 & 0.1380 & 0.0332 & 0.0581 & 0.0463 \\
\hline & {$[0.050]$} & {$[0.049]$} & {$[0.042]^{* * *}$} & {$[0.065]$} & {$[0.045]$} & [0.049] \\
\hline Observations & 1,073 & 1,073 & 1,073 & 842 & 1,073 & 1,073 \\
\hline R-squared & 0.155 & 0.156 & 0.163 & 0.190 & 0.163 & 0.158 \\
\hline Number of country & 12 & 12 & 12 & 12 & 12 & 12 \\
\hline
\end{tabular}


TABLE 9: Buffer Effect of the Stock of SWF assets on REER

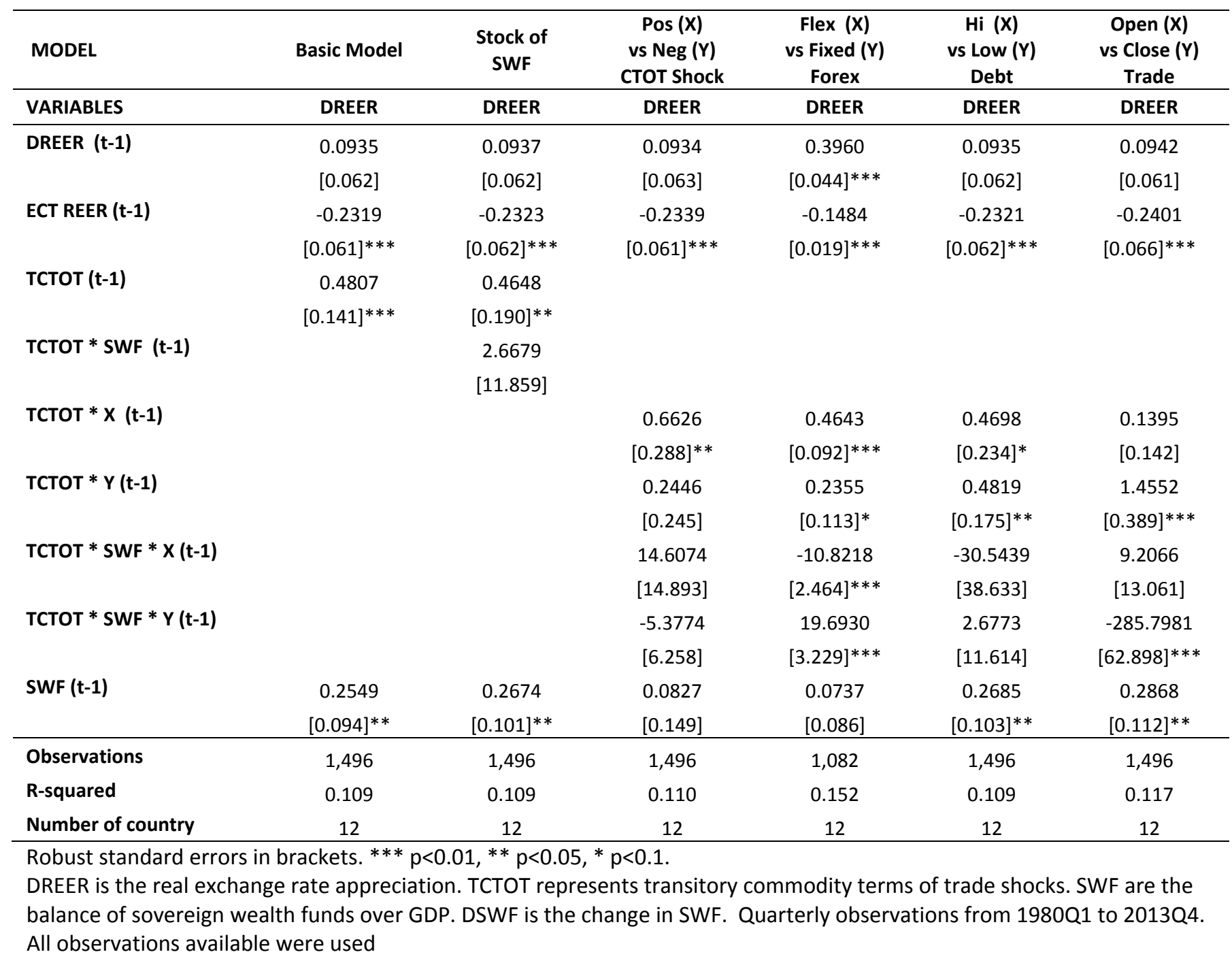


TABLE 10: Buffer Effect of the Stock of SWF assets on Output Growth

\begin{tabular}{|c|c|c|c|c|c|c|}
\hline MODEL & Basic Model & $\begin{array}{l}\text { Stock of } \\
\text { SWF }\end{array}$ & $\begin{array}{c}\text { Pos (X) } \\
\text { vs Neg (Y) } \\
\text { CTOT Shock }\end{array}$ & $\begin{array}{c}\text { Flex }(\mathrm{X}) \\
\text { vs Fixed }(\mathrm{Y}) \\
\text { Forex } \\
\end{array}$ & $\begin{array}{c}\text { Hi }(X) \\
\text { vs Low }(Y) \\
\text { Debt } \\
\end{array}$ & $\begin{array}{c}\text { Open }(\mathrm{X}) \\
\text { vs Close }(\mathrm{Y}) \\
\text { Trade } \\
\end{array}$ \\
\hline VARIABLES & DRGDP & DRGDP & DRGDP & DRGDP & DRGDP & DRGDP \\
\hline \multirow[t]{2}{*}{ DRGDP (t-1) } & 0.1656 & 0.1653 & 0.1635 & 0.1634 & 0.1662 & 0.1665 \\
\hline & {$[0.054]^{* *}$} & {$[0.054]^{* *}$} & {$[0.054]^{* *}$} & {$[0.057]^{* *}$} & {$[0.053]^{* * *}$} & {$[0.055]^{* *}$} \\
\hline \multirow[t]{2}{*}{ ECT RGDP (t-1) } & -0.2668 & -0.2689 & -0.2665 & -0.3265 & -0.2727 & -0.2703 \\
\hline & {$[0.044]^{* * *}$} & {$[0.044]^{* * *}$} & {$[0.043]^{* * *}$} & {$[0.023]^{* * *}$} & {$[0.044]^{* * *}$} & {$[0.042]^{* * *}$} \\
\hline \multirow[t]{2}{*}{ тстот (t-1) } & 0.2163 & 0.1864 & & & & \\
\hline & {$[0.062]^{* * *}$} & {$[0.058]^{* * *}$} & & & & \\
\hline \multirow[t]{2}{*}{ Tстот * SWF (t-1) } & & 3.1976 & & & & \\
\hline & & {$[2.053]$} & & & & \\
\hline \multirow[t]{2}{*}{ ТСТОТ * X (t-1) } & & & 0.1309 & 0.2161 & 0.1131 & 0.2041 \\
\hline & & & {$[0.057]^{* *}$} & {$[0.115]^{*}$} & {$[0.085]$} & {$[0.047]^{* * *}$} \\
\hline \multirow[t]{2}{*}{ TСТОТ * Y (t-1) } & & & 0.2413 & 0.1905 & 0.2756 & 0.0131 \\
\hline & & & {$[0.071]^{* * *}$} & {$[0.053]^{* * *}$} & {$[0.031]^{* * *}$} & {$[0.200]$} \\
\hline \multirow[t]{2}{*}{ тстот * SWF * X (t-1) } & & & 2.5032 & 0.3075 & -20.9137 & 2.8718 \\
\hline & & & [3.260] & [2.125] & {$[8.658]^{* *}$} & {$[2.095]$} \\
\hline \multirow[t]{2}{*}{ ТСТОТ * SWF * Y (t-1) } & & & 3.7074 & 8.9772 & 1.9230 & 36.8200 \\
\hline & & & {$[2.009]^{*}$} & {$[1.657]^{* * *}$} & {$[2.072]$} & [40.583] \\
\hline \multirow[t]{2}{*}{$\operatorname{RES}(t-1)$} & -0.1157 & -0.0981 & -0.0827 & -0.1462 & -0.0887 & -0.0983 \\
\hline & {$[0.077]$} & {$[0.074]$} & {$[0.083]$} & {$[0.116]$} & {$[0.076]$} & {$[0.072]$} \\
\hline Observations & 1,073 & 1,073 & 1,073 & 842 & 1,073 & 1,073 \\
\hline R-squared & 0.155 & 0.157 & 0.158 & 0.201 & 0.161 & 0.158 \\
\hline Number of country & 12 & 12 & 12 & 12 & 12 & 12 \\
\hline
\end{tabular}

Robust standard errors in brackets. ${ }^{* * *} p<0.01,{ }^{* *} p<0.05,{ }^{*} p<0.1$.

DRGDP represents real output growth. TCTOT represents transitory commodity terms of trade shocks. SWF are the balance of sovereign wealth funds over GDP. DSWF is the change in SWF Quarterly observations from 1980Q1 to 2013 Q4.

Observations under hyperinflation episodes (>100\% inflation) are not included. 
TABLE 11: Buffer effects of International Liquidity Management by Periods of Interest The first three columns are for DREER and the last three for DRGDP

\begin{tabular}{|c|c|c|c|c|c|c|}
\hline VARIABLES & $\begin{array}{c}X=\text { RES } \\
Y=\text { DREER }\end{array}$ & $\begin{array}{c}X=\text { DRES } \\
Y=\text { DREER }\end{array}$ & $\begin{array}{c}X=S W F \\
Y=\text { DREER }\end{array}$ & $\begin{array}{c}X=R E S \\
Y=D R G D P\end{array}$ & $\begin{array}{c}\mathrm{X}=\mathrm{DRES} \\
\mathrm{Y}=\mathrm{DRGDP}\end{array}$ & $\begin{array}{c}X=S W F \\
Y=D R G D P\end{array}$ \\
\hline \multirow[t]{2}{*}{$Y(t-1)$} & 0.0958 & 0.0961 & 0.0952 & 0.1550 & 0.1554 & 0.1460 \\
\hline & {$[0.057]$} & {$[0.057]$} & {$[0.058]$} & {$[0.049]^{* * *}$} & {$[0.047]^{* * *}$} & {$[0.050]^{* *}$} \\
\hline \multirow[t]{2}{*}{ ECT Y (t-1) } & -0.2469 & -0.2445 & -0.2414 & -0.2831 & -0.2837 & -0.2802 \\
\hline & {$[0.077]^{* * *}$} & {$[0.075]^{* * *}$} & {$[0.070]^{* * *}$} & {$[0.038]^{* * *}$} & {$[0.038]^{* * *}$} & {$[0.038]^{* * *}$} \\
\hline \multirow[t]{2}{*}{ Стот (t-1) } & 1.8291 & 0.6369 & 0.5151 & 0.2249 & 0.2696 & 0.2048 \\
\hline & {$[0.563]^{* * *}$} & {$[0.243]^{* *}$} & {$[0.287]$} & {$[0.148]$} & {$[0.074]^{* * *}$} & {$[0.061]^{* * *}$} \\
\hline \multirow[t]{2}{*}{ стот * GM (t-1) } & -0.4119 & -0.4091 & -0.6468 & -0.1828 & -0.1245 & 0.0060 \\
\hline & {$[1.003]$} & {$[0.311]$} & {$[0.514]$} & [0.355] & {$[0.061]^{*}$} & {$[0.101]$} \\
\hline \multirow[t]{2}{*}{ Стот * GR (t-1) } & -1.9051 & -0.3664 & -0.2102 & 0.0900 & -0.0678 & -0.0132 \\
\hline & {$[0.664]^{* *}$} & {$[0.260]$} & {$[0.261]$} & {$[0.206]$} & {$[0.059]$} & {$[0.054]$} \\
\hline \multirow[t]{2}{*}{ Стот * AGR (t-1) } & -1.2083 & -0.2749 & -0.0492 & 0.0669 & -0.0374 & 0.0437 \\
\hline & {$[0.783]$} & {$[0.520]$} & [0.644] & {$[0.166]$} & {$[0.085]$} & {$[0.088]$} \\
\hline \multirow[t]{2}{*}{ Стот * $\mathrm{X}(\mathrm{t}-1)$} & -10.8622 & -15.1314 & 20.4624 & 0.4305 & 1.3378 & 7.5401 \\
\hline & {$[4.276]^{* *}$} & {$[3.308]^{* * *}$} & {$[7.151]^{* *}$} & [0.983] & {$[3.538]$} & {$[1.099]^{* * *}$} \\
\hline \multirow[t]{2}{*}{ Стот * $\mathrm{X} * \mathrm{GM}(\mathrm{t}-1)$} & 1.1372 & -5.6076 & 11.2714 & 0.5731 & 3.3774 & -10.7666 \\
\hline & [7.114] & [17.919] & [15.753] & {$[2.664]$} & [9.293] & {$[7.366]$} \\
\hline \multirow[t]{2}{*}{ СтOT * $\mathrm{X} * \mathrm{GR}(\mathrm{t}-1)$} & 13.1715 & 31.6379 & -28.6769 & -1.1617 & -0.2277 & -6.6374 \\
\hline & {$[4.352]^{* *}$} & {$[6.339]^{* * *}$} & {$[4.763]^{* * *}$} & [1.207] & {$[2.834]$} & {$[1.586]^{* * *}$} \\
\hline \multirow[t]{2}{*}{ Стот * $\mathrm{X} *$ AGR (t-1) } & 8.5414 & -15.4449 & -31.6551 & -1.0388 & -19.3620 & -9.6771 \\
\hline & {$[4.292]^{*}$} & {$[72.282]$} & {$[9.424]^{* * *}$} & {$[1.068]$} & [14.101] & {$[3.120]^{* *}$} \\
\hline \multirow[t]{2}{*}{$\operatorname{RES}(t-1)$} & 0.0999 & 0.0937 & & 0.0113 & 0.0090 & \\
\hline & {$[0.057]$} & {$[0.056]$} & & {$[0.011]$} & {$[0.011]$} & \\
\hline \multirow[t]{2}{*}{ DRES (t-1) } & & -0.0302 & & & 0.0691 & \\
\hline & & {$[0.318]$} & & & {$[0.066]$} & \\
\hline \multirow[t]{2}{*}{ SWF (t-1) } & & & 0.0137 & & & -0.1472 \\
\hline & & & [0.094] & & & {$[0.113]$} \\
\hline Observations & 1,496 & 1,496 & 1,496 & 982 & 982 & 982 \\
\hline R-squared & 0.122 & 0.120 & 0.117 & 0.188 & 0.189 & 0.196 \\
\hline Number of country & 12 & 12 & 12 & 12 & 12 & 12 \\
\hline
\end{tabular}


Table 12: Error Correction Model for the Change of Reserves and Change of SWF

\begin{tabular}{|c|c|c|c|c|c|c|}
\hline & $\begin{array}{c}\text { FULL } \\
\text { SAMPLE }\end{array}$ & 2003-2013 & $\begin{array}{c}\text { SWF } \\
\text { COUNTRIES }\end{array}$ & $\begin{array}{c}\text { FULL } \\
\text { SAMPLE }\end{array}$ & $2003-2013$ & $\begin{array}{c}\text { SWF } \\
\text { COUNTRIES }\end{array}$ \\
\hline VARIABLES & DRES & DRES & DRES & DSWF & DSWF & DSWF \\
\hline \multirow[t]{2}{*}{ DSWF (t) } & -0.4857 & -0.3445 & -0.5252 & & & \\
\hline & {$[0.229]^{*}$} & {$[0.166]^{*}$} & {$[0.099]^{* * *}$} & & & \\
\hline \multirow[t]{2}{*}{ DSWF (t-1) } & 0.0729 & -0.1162 & 0.2490 & 0.4776 & 0.4180 & 0.5825 \\
\hline & {$[0.400]$} & [0.432] & {$[0.163]$} & {$[0.122]^{* * *}$} & {$[0.145]^{* *}$} & {$[0.053]^{* * *}$} \\
\hline \multirow[t]{2}{*}{ DSWF (t-2) } & -0.0735 & -0.0583 & -0.2617 & 0.1845 & 0.1948 & 0.1448 \\
\hline & {$[0.082]$} & {$[0.138]$} & {$[0.247]$} & {$[0.056]^{* * *}$} & {$[0.050]^{* * *}$} & {$[0.052]^{* *}$} \\
\hline \multirow[t]{2}{*}{ DSWF (t-3) } & 0.1444 & 0.0929 & -0.0652 & 0.0633 & 0.0731 & 0.0423 \\
\hline & [0.289] & {$[0.266]$} & {$[0.357]$} & {$[0.064]$} & {$[0.061]$} & {$[0.060]$} \\
\hline $\begin{array}{c}\text { P-value } \\
\text { For Joint Sig }\end{array}$ & 0.000 & 0.001 & 0.01 & & & \\
\hline \multirow[t]{2}{*}{ DRES (t) } & & & & -0.0061 & -0.0115 & -0.0263 \\
\hline & & & & {$[0.004]$} & {$[0.008]$} & [0.017] \\
\hline \multirow[t]{2}{*}{ DRES (t-1) } & -0.0111 & 0.0741 & -0.1777 & 0.0058 & 0.0130 & 0.0233 \\
\hline & {$[0.054]$} & {$[0.080]$} & {$[0.131]$} & {$[0.003]^{*}$} & {$[0.006]^{* *}$} & {$[0.016]$} \\
\hline \multirow[t]{2}{*}{ DRES (t-2) } & 0.0778 & 0.0936 & -0.0642 & -0.0011 & 0.0011 & 0.0096 \\
\hline & {$[0.032]^{* *}$} & {$[0.052]^{*}$} & {$[0.120]$} & {$[0.002]$} & [0.003] & [0.005] \\
\hline \multirow[t]{2}{*}{ DRES (t-3) } & -0.0232 & -0.0550 & -0.0273 & -0.0022 & -0.0018 & 0.0192 \\
\hline & {$[0.026]$} & {$[0.054]$} & {$[0.027]$} & {$[0.003]$} & {$[0.004]$} & {$[0.022]$} \\
\hline $\begin{array}{c}\text { P-value } \\
\text { For Joint Sig }\end{array}$ & & & & 0.05 & 0.25 & 0.04 \\
\hline \multirow[t]{2}{*}{ RES STOCK (t-1) } & -0.0192 & -0.0239 & -0.0236 & -0.0008 & -0.0015 & -0.0023 \\
\hline & {$[0.012]$} & {$[0.010]^{* *}$} & [0.013] & {$[0.001]$} & {$[0.003]$} & {$[0.010]$} \\
\hline \multirow[t]{2}{*}{ SWF STOCK (t-1) } & -0.0075 & 0.0566 & 0.0952 & -0.0405 & -0.0635 & -0.0444 \\
\hline & {$[0.032]$} & {$[0.040]$} & {$[0.068]$} & {$[0.010]^{* * *}$} & {$[0.015]^{* * *}$} & {$[0.006]^{* * *}$} \\
\hline Constant & Yes & Yes & Yes & Yes & Yes & Yes \\
\hline Fixed Effects & Yes & Yes & Yes & Yes & Yes & Yes \\
\hline Year Effects & Yes & Yes & Yes & Yes & Yes & Yes \\
\hline Observations & 1,716 & 624 & 379 & 1,716 & 624 & 379 \\
\hline R-squared & 0.132 & 0.177 & 0.308 & 0.449 & 0.445 & 0.614 \\
\hline Number of id & 13 & 13 & 6 & 13 & 13 & 6 \\
\hline
\end{tabular}

Robust standard errors in brackets. ${ }^{* * *} p<0.01, * * p<0.05, * p<0.1$.

RES STOCK is the total international reserves over GDP. DRES represents 1 period change in RES STOCK. SWF STOCK is the balance of sovereign wealth funds over GDP. DSWF represents 1 period change in SWF STOCK. Full sample corresponds to quarterly observations from $1980 \mathrm{Q} 1$ to $2013 \mathrm{Q} 4$. 
TABLE 13: AUGMENTED TAYLOR RULE

\begin{tabular}{|c|c|c|c|c|}
\hline METHODOLOGY & LSDV & LSDV & LSDV & HT \\
\hline VARIABLES & POLICY RATE & POLICY RATE & POLICY RATE & POLICY RATE \\
\hline \multirow[t]{2}{*}{ POLICY RATE (t-1) } & 0.8406 & 0.8529 & 0.8572 & 0.8042 \\
\hline & {$[0.038]^{* * *}$} & {$[0.030]^{* * *}$} & {$[0.028]^{* * *}$} & {$[0.021]^{* * *}$} \\
\hline \multirow[t]{2}{*}{ POLICY RATE * IT (t-1) } & & & -0.1917 & -0.1682 \\
\hline & & & {$[0.049]^{* * *}$} & {$[0.043]^{* * *}$} \\
\hline \multirow[t]{2}{*}{ ECT RGDP (t-1) } & 38.3912 & 35.1963 & 32.6971 & 28.3668 \\
\hline & {$[6.181]^{* * *}$} & {$[5.982]^{* * *}$} & {$[8.087]^{* * *}$} & {$[7.916]^{* * *}$} \\
\hline \multirow[t]{2}{*}{ ECT RGDP * IT (t-1) } & & & -6.0744 & -1.8203 \\
\hline & & & [12.187] & [15.827] \\
\hline \multirow[t]{2}{*}{ INF (t-1) } & 4.4019 & 2.7090 & 0.5896 & -2.0895 \\
\hline & {$[3.042]$} & [3.099] & {$[3.245]$} & {$[2.854]$} \\
\hline \multirow[t]{2}{*}{ INF * IT (t-1) } & & & 10.9982 & 2.4312 \\
\hline & & & {$[4.928]^{* *}$} & [9.057] \\
\hline \multirow[t]{2}{*}{ DREER (t-1) } & & 12.2343 & 19.6533 & 17.8656 \\
\hline & & {$[6.515]^{*}$} & {$[9.748]^{*}$} & {$[4.901]^{* * *}$} \\
\hline \multirow[t]{2}{*}{ DREER * IT (t-1) } & & & -21.0437 & -18.6527 \\
\hline & & & {$[10.494]^{*}$} & {$[7.736]^{* *}$} \\
\hline Observations & 1,023 & 1,023 & 1,023 & 1,023 \\
\hline R-squared & 0.773 & 0.775 & 0.782 & \\
\hline Number of country & 13 & 13 & 13 & 13 \\
\hline
\end{tabular}

Robust standard errors in brackets. ${ }^{* * *} \mathrm{p}<0.01,{ }^{* *} \mathrm{p}<0.05, * \mathrm{p}<0.1$.

ECM GDP represents real output gap. IT is a dummy with value 1 if the country is targeting inflation 0 otherwise. DREER represents real exchange rate appreciation. Quarterly observations from 1980Q1 to 2013Q4. Observations under hyperinflation episodes (>40\% inflation) and with Policy rates above 100 percent are not included.

HT - the Hausman-Taylor regression with all dependent variables considered as potentially endogenous. 
TABLE 14: The Buffering of International Liquidity Management and Inflation Targeting

\begin{tabular}{|c|c|c|c|c|}
\hline VARIABLES & $\begin{array}{c}(1) \\
Y=\text { DREER }\end{array}$ & $\begin{array}{c}(2) \\
Y=\text { DREER }\end{array}$ & $\begin{array}{c}(3) \\
Y=\text { DRGDP }\end{array}$ & $\begin{array}{c}(4) \\
Y=\text { DRGDP }\end{array}$ \\
\hline \multirow[t]{2}{*}{$Y(t-1)$} & 0.0928 & 0.0930 & 0.1632 & 0.1626 \\
\hline & {$[0.060]$} & {$[0.062]$} & {$[0.052]^{* * *}$} & {$[0.053]^{* *}$} \\
\hline \multirow[t]{2}{*}{ ECT Y (t-1) } & -0.2370 & -0.2323 & -0.2672 & -0.2681 \\
\hline & {$[0.068]^{* * *}$} & {$[0.062]^{* * *}$} & {$[0.045]^{* * *}$} & {$[0.044]^{* * *}$} \\
\hline \multirow[t]{2}{*}{ Стот (t-1) } & 0.8206 & 0.4369 & 0.2807 & 0.1663 \\
\hline & {$[0.234]^{* * *}$} & {$[0.204]^{*}$} & {$[0.069]^{* * *}$} & {$[0.063]^{* *}$} \\
\hline \multirow[t]{2}{*}{ СTOT * IT (t-1) } & -1.3213 & -0.0374 & -0.4233 & 0.0616 \\
\hline & {$[0.615]^{*}$} & {$[0.336]$} & {$[0.171]^{* *}$} & {$[0.126]$} \\
\hline \multirow[t]{2}{*}{ СТОT * RES (t-1) } & -2.7496 & & -0.5985 & \\
\hline & {$[0.642]^{* * *}$} & & {$[0.213]^{* *}$} & \\
\hline \multirow[t]{2}{*}{ СTOT * RES * IT (t-1) } & 7.6299 & & 3.1150 & \\
\hline & {$[3.202]^{* *}$} & & {$[0.875]^{* * *}$} & \\
\hline \multirow[t]{2}{*}{ Стот * SWF (t-1) } & & 20.9043 & & 8.7804 \\
\hline & & {$[5.864]^{* * *}$} & & {$[1.437]^{* * *}$} \\
\hline \multirow[t]{2}{*}{ Стот * SWF * IT (t-1) } & & -27.1766 & & -9.0664 \\
\hline & & {$[6.572]^{* * *}$} & & {$[2.115]^{* * *}$} \\
\hline \multirow[t]{2}{*}{ IT DUMMY } & -0.0046 & 0.0010 & 0.0019 & 0.0032 \\
\hline & {$[0.009]$} & {$[0.007]$} & {$[0.001]$} & {$[0.002]^{*}$} \\
\hline \multirow[t]{2}{*}{ RES (t-1) } & 0.1189 & & 0.0141 & \\
\hline & {$[0.046]^{* *}$} & & {$[0.009]$} & \\
\hline \multirow[t]{2}{*}{ SWF (t-1) } & & 0.2097 & & -0.1283 \\
\hline & & {$[0.112]^{*}$} & & {$[0.087]$} \\
\hline Observations & 1,496 & 1,496 & 1,113 & 1,113 \\
\hline R-squared & 0.115 & 0.110 & 0.184 & 0.188 \\
\hline Number of country & 12 & 12 & 12 & 12 \\
\hline
\end{tabular}

Robust standard errors in brackets. ${ }^{* * *} p<0.01,{ }^{* *} p<0.05, * p<0.1$.

DRGDP represents real output growth. TCTOT represents transitory commodity terms of trade shocks. IT is a dummy with value 1 if the country is targeting inflation 0 otherwise. RES are the stock of international reserves over GDP. DRES is the change in RES. SWF are the balance of sovereign wealth funds over GDP. Quarterly observations from 1980Q1 to 2013 Q4. For output regressions observations under hyperinflation episodes (>100\% inflation) are not included. 
Figure 1A: CTOT shock volatility vs. Accumulation of Foreign Reserve Assets.

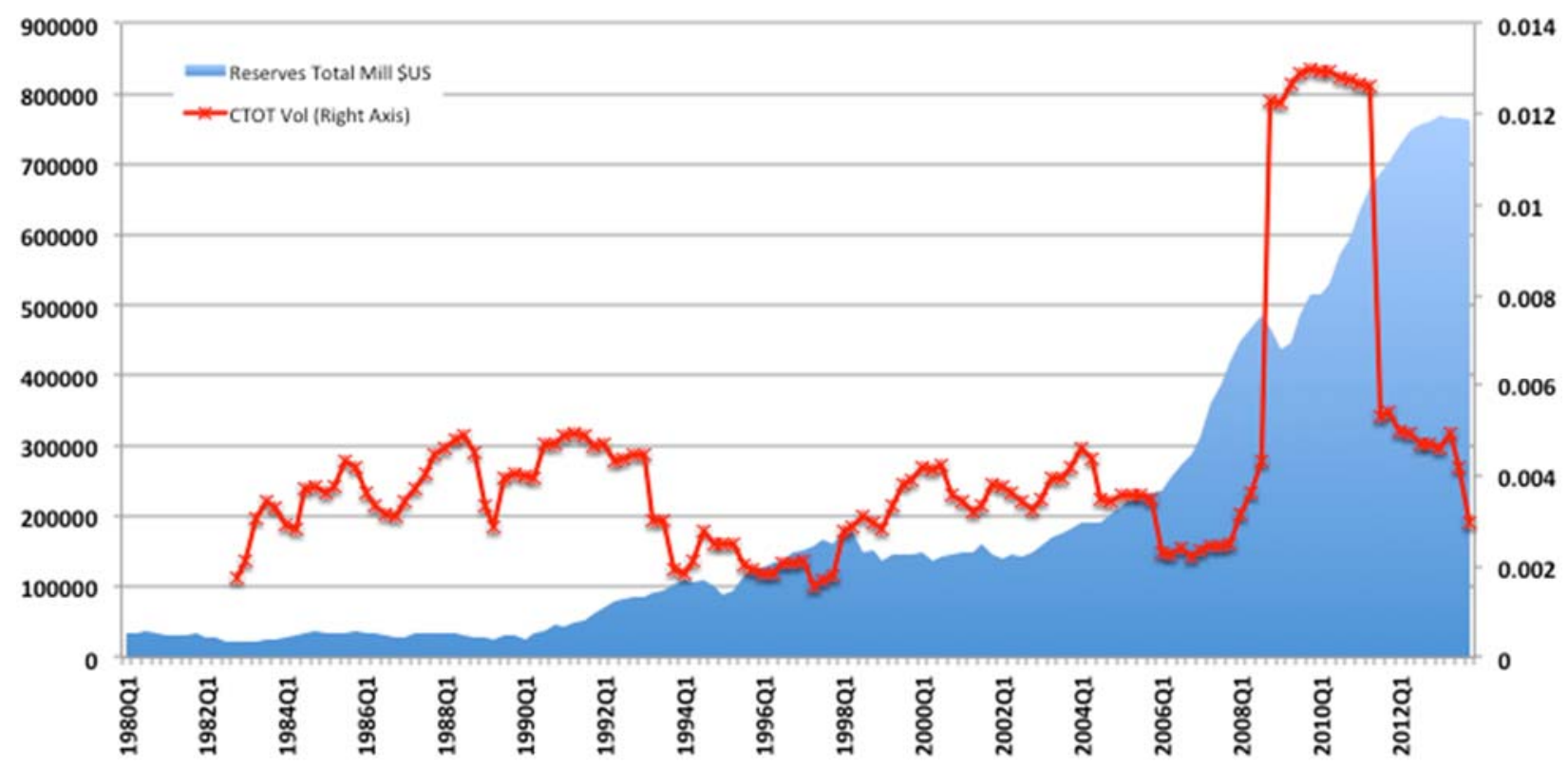

Figure 1B: CTOT shock volatility vs. Accumulation of Assets in Stabilization Sovereign Wealth Funds

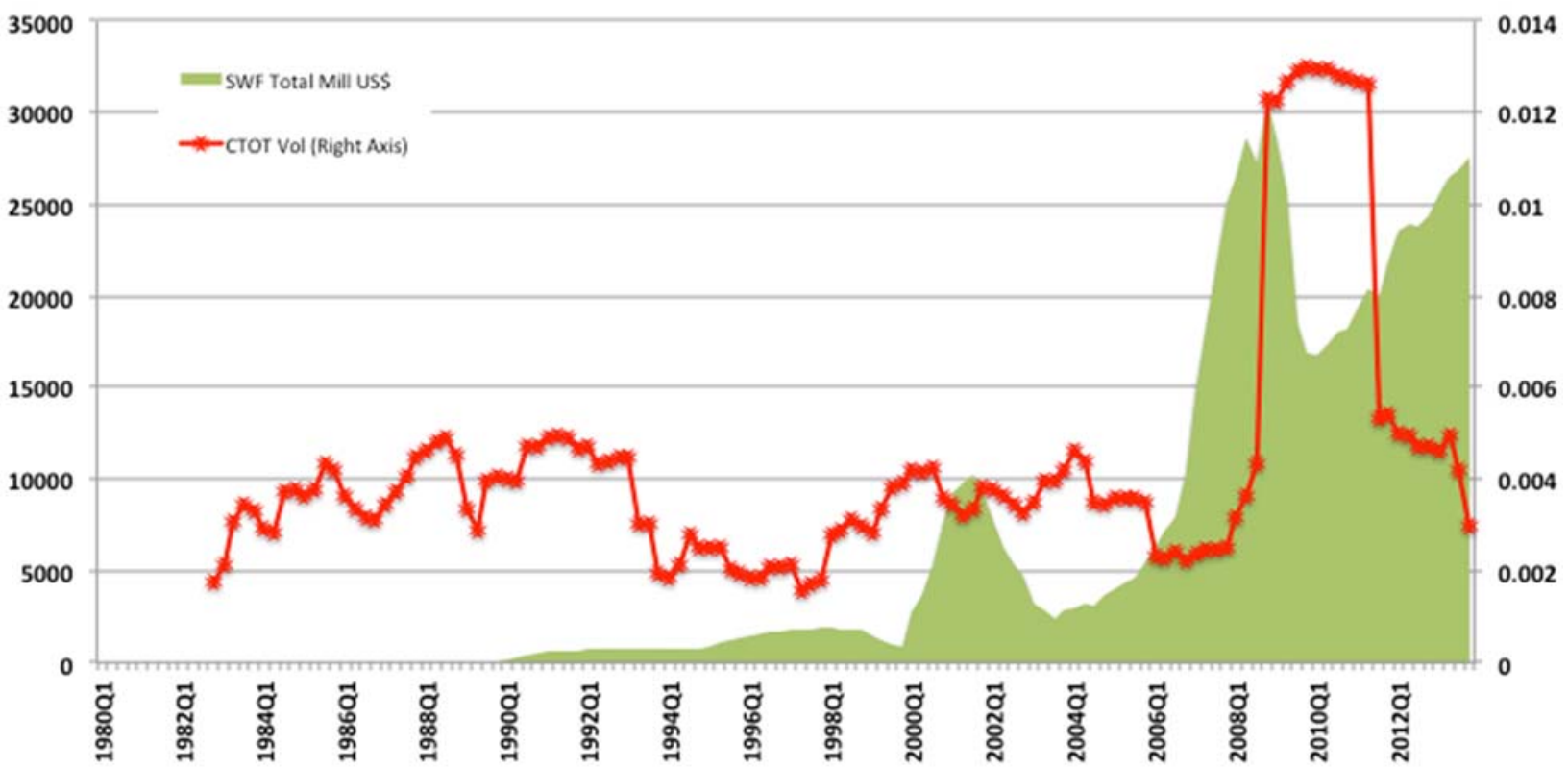


Figure 1C: SWF balances by Country

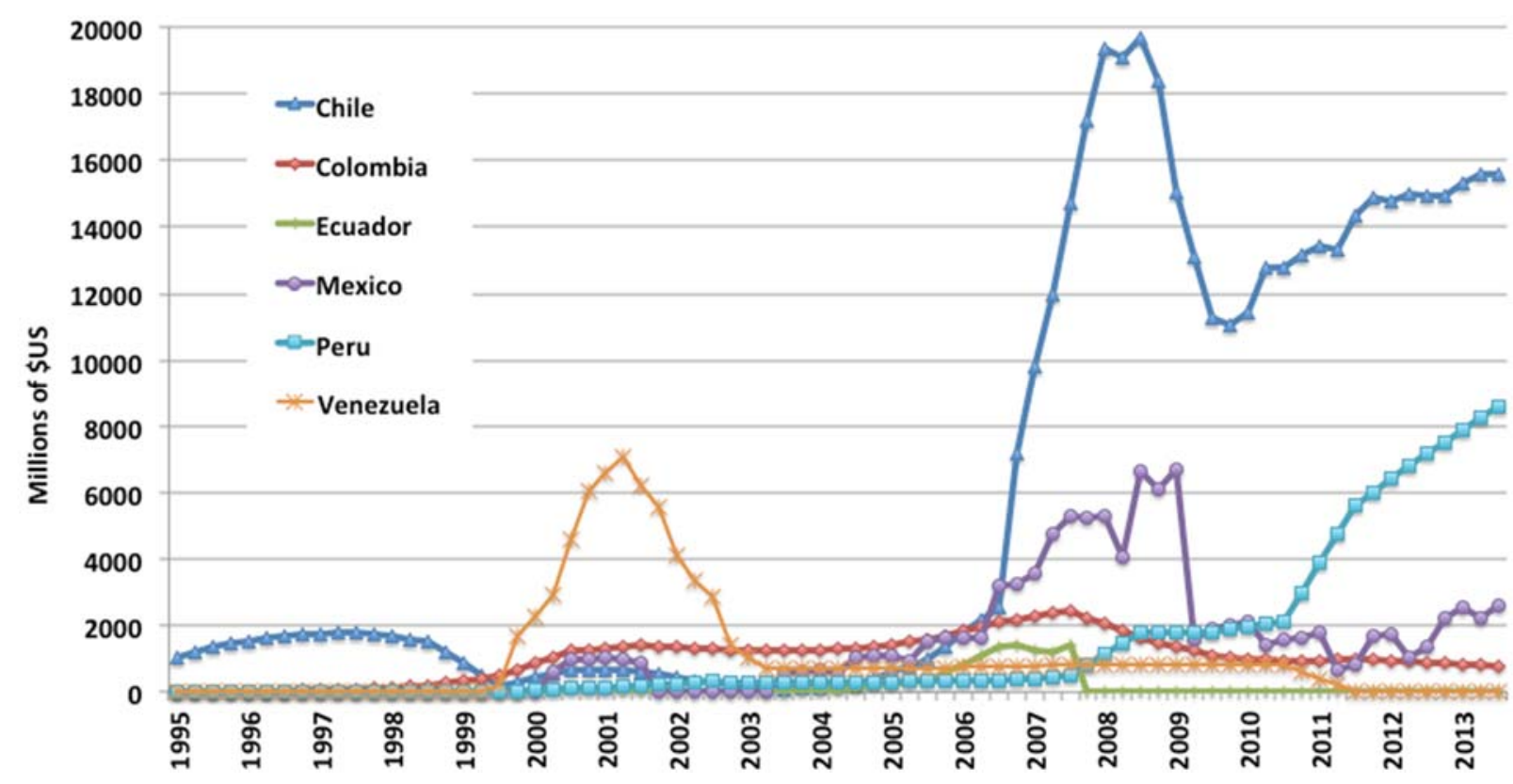

Figure 2: REER IRF to 1\% CTOT shock under high and low stock of reserves

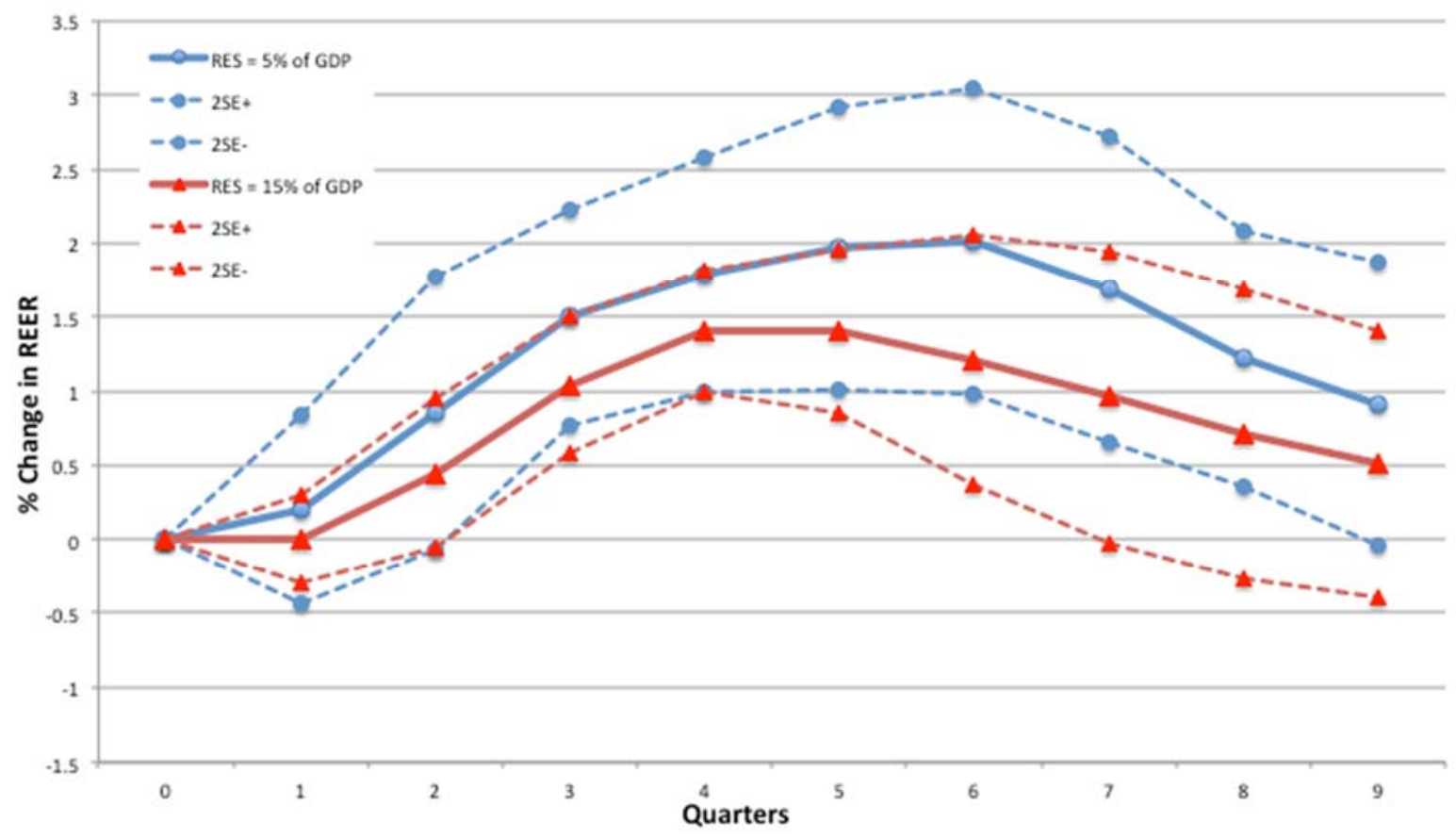


Figure 3A: OUTPUT IRF to 1\% CTOT after POSITIVE CTOT Shocks

\section{PERCENT INCREASE IN CTOT}

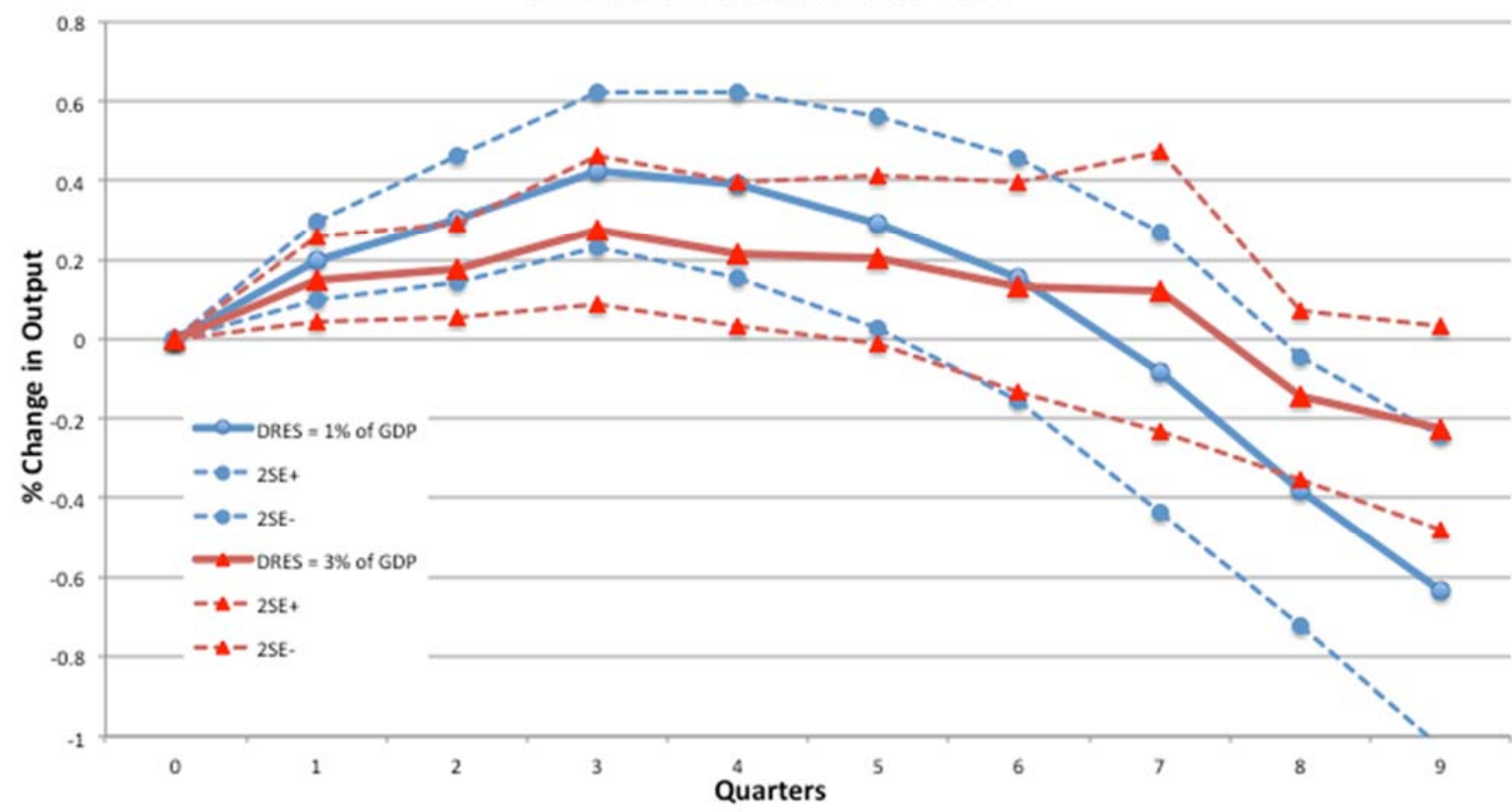

Figure 3B: OUTPUT IRF to 1\% CTOT after NEGATIVE CTOT Shocks

1 PERCENT DECREASE IN CTOT

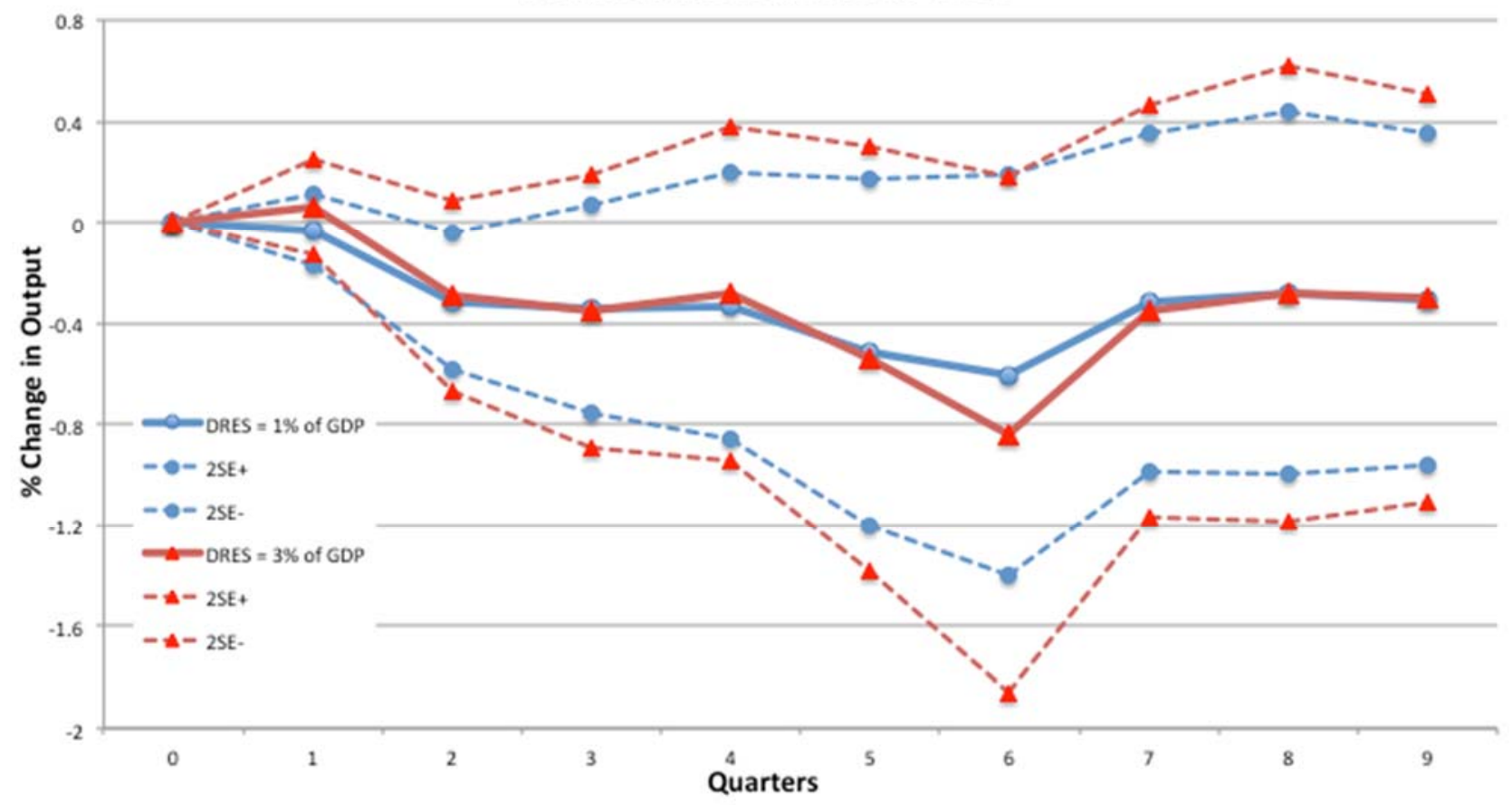


Figure 4: REER IRF to 1\% CTOT under high and low stock of reserves by Periods
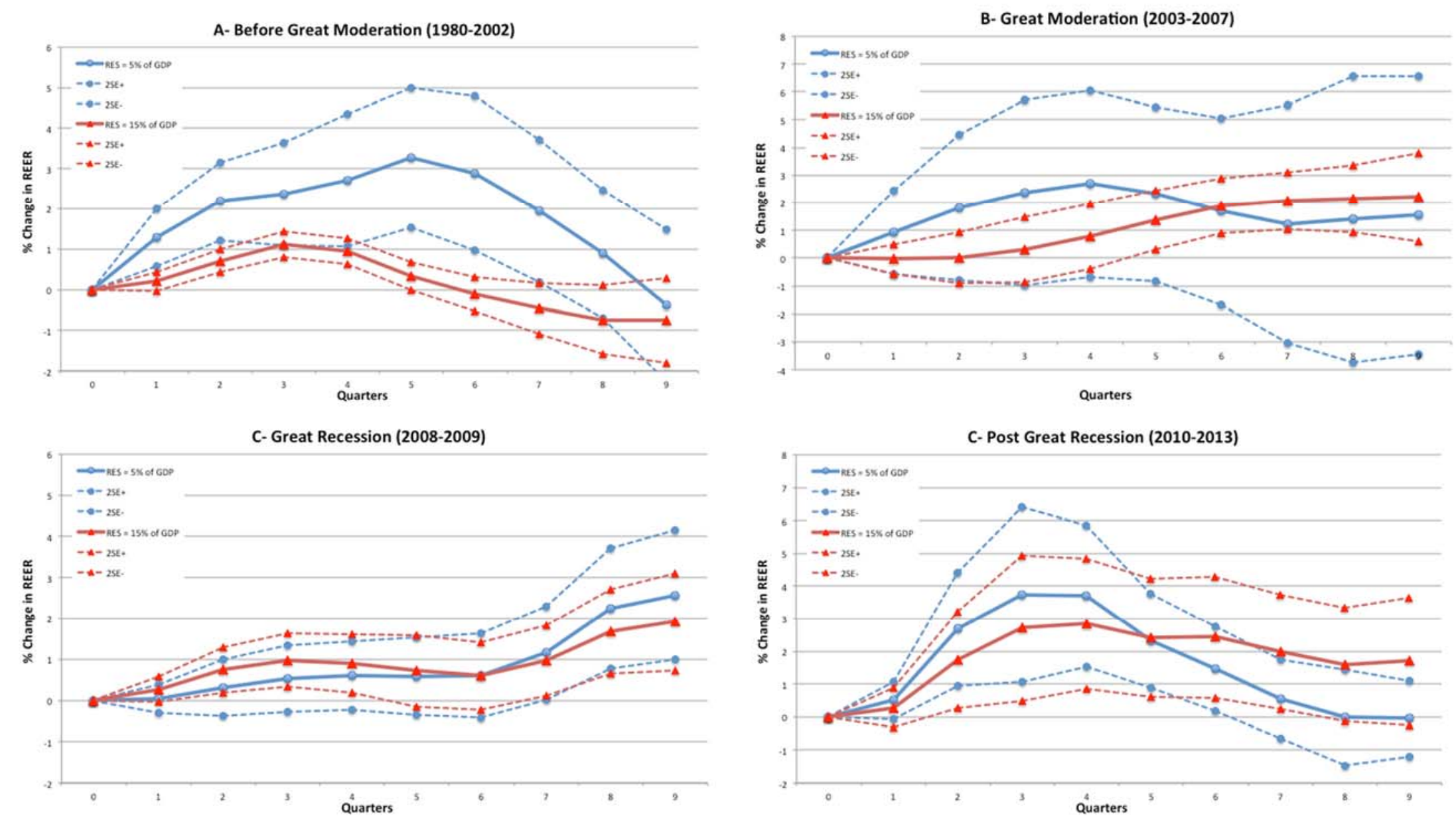
Figure 5: REER IRF to $1 \%$ CTOT under high and low stock of SWF by Periods

\section{A- Great Recession (2008-2009)}

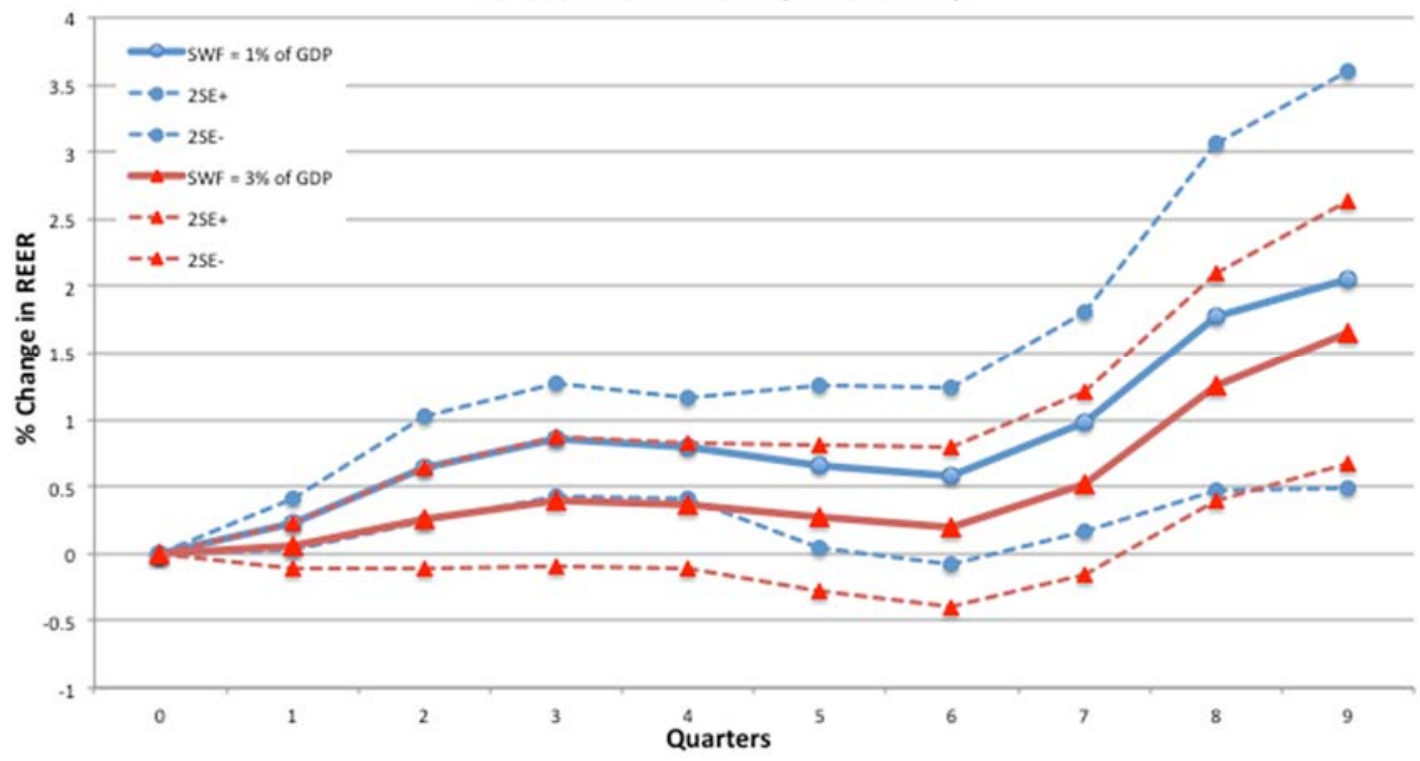

B- Post Great Recession (2010-2013)

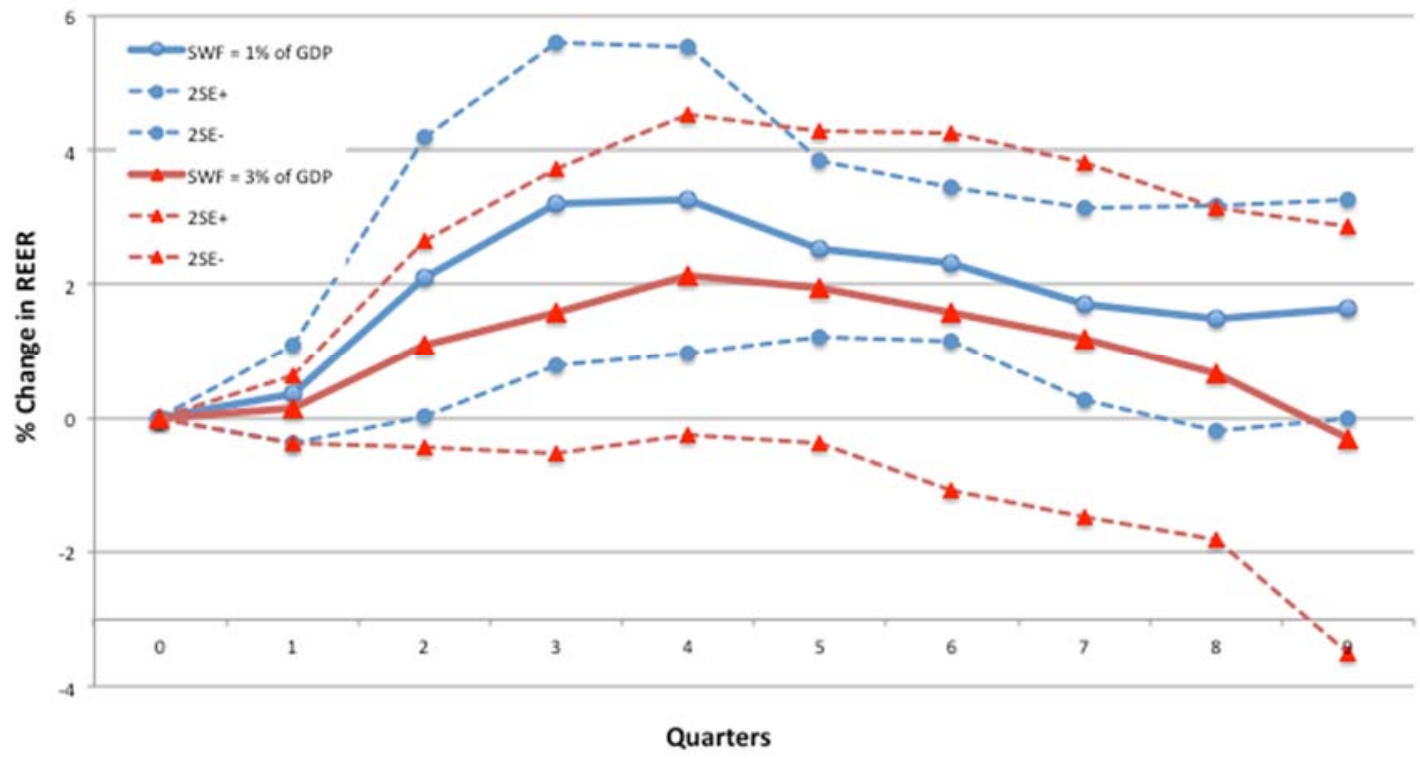


Figure 6: Dynamic relationship between DRES and DWF: All Countries from 2003 to 2013

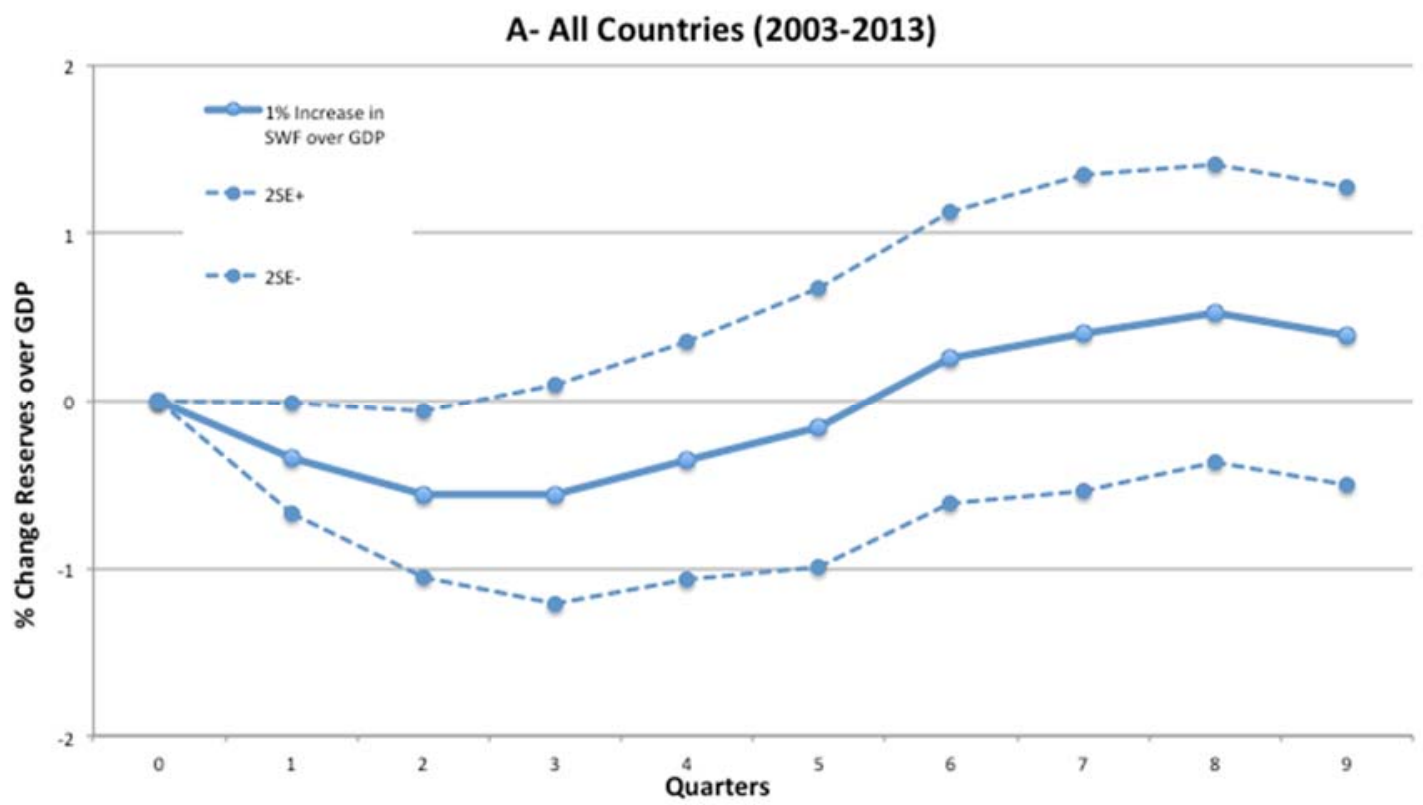

B-All Countries (2003-2013)

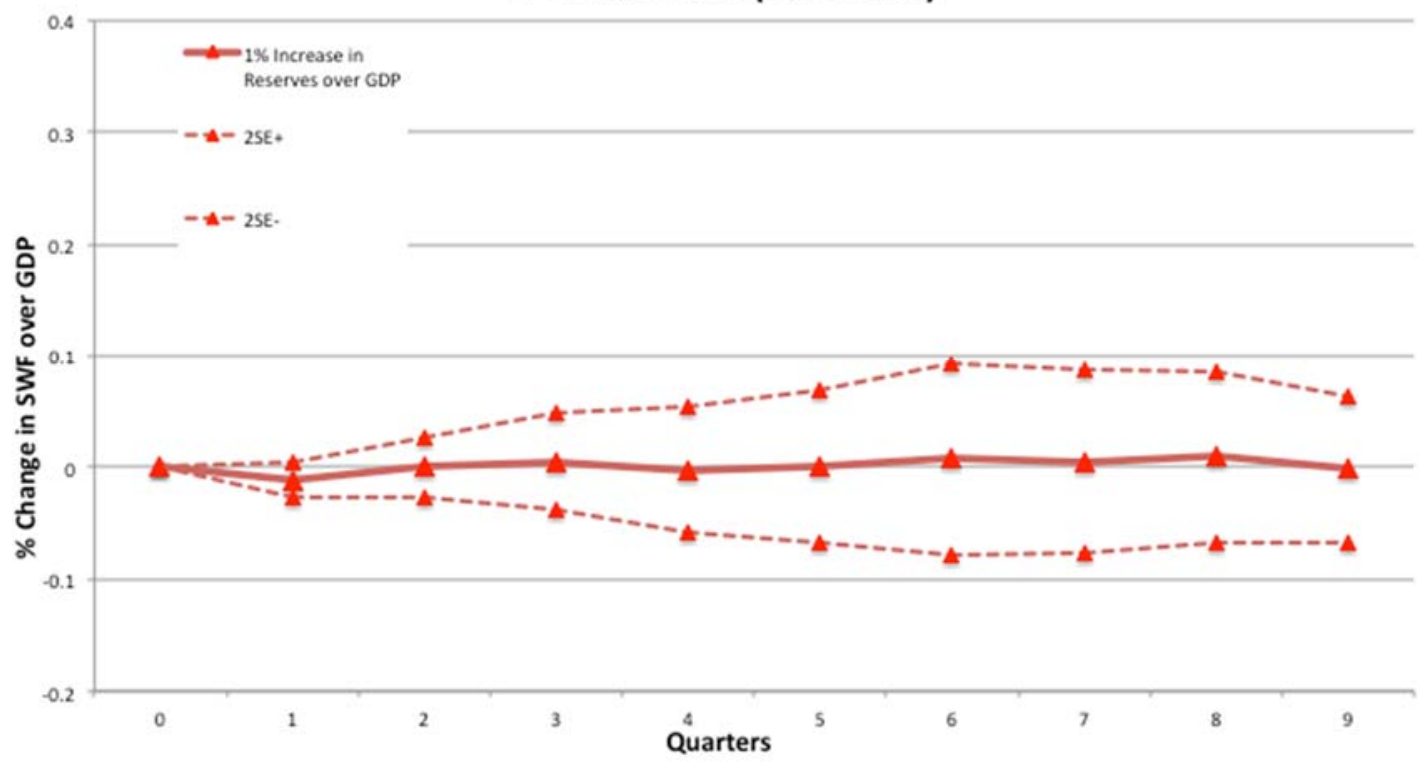


Figure 7: Dynamic relationship between DRES and DWF: SWF Countries / All Quarters

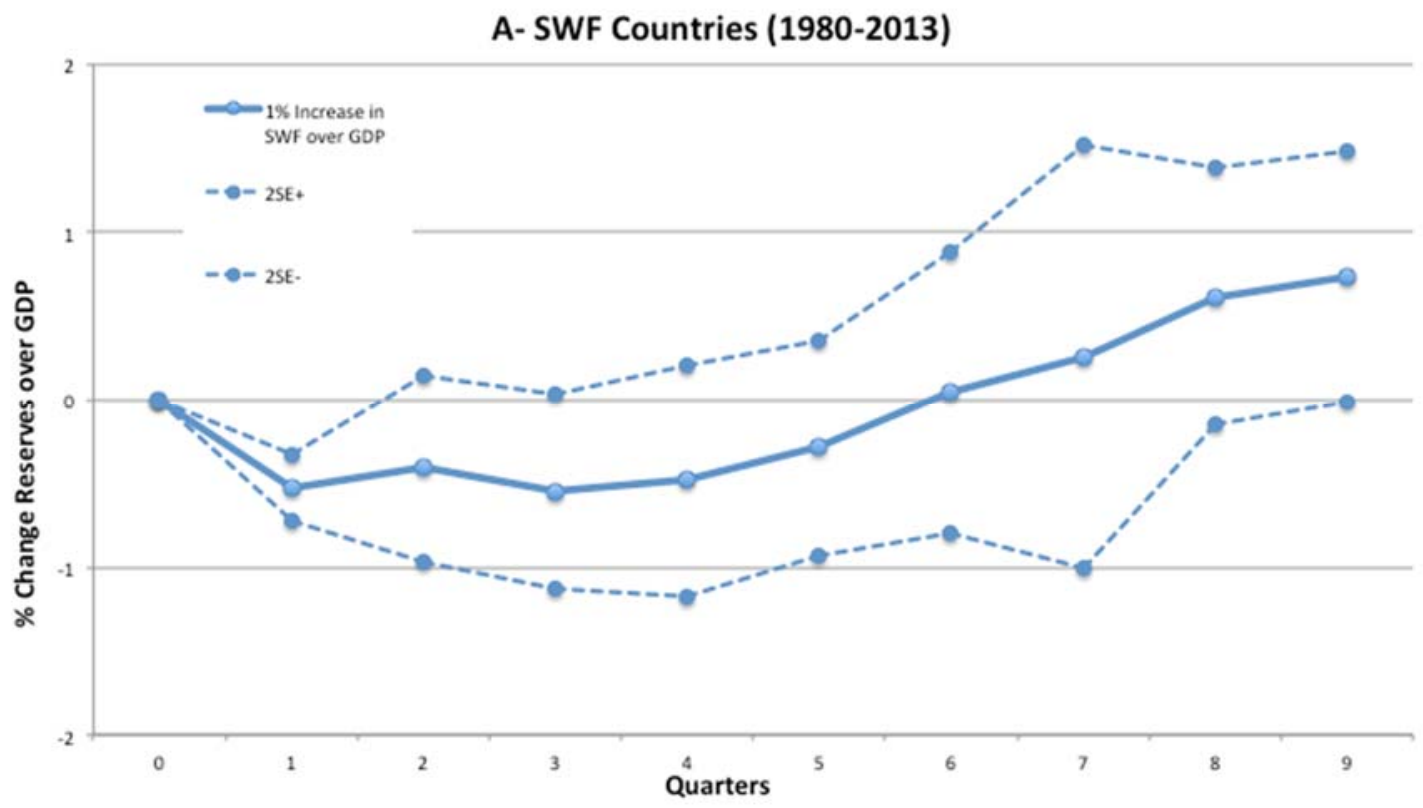

B- SWF Countries (1980-2013)

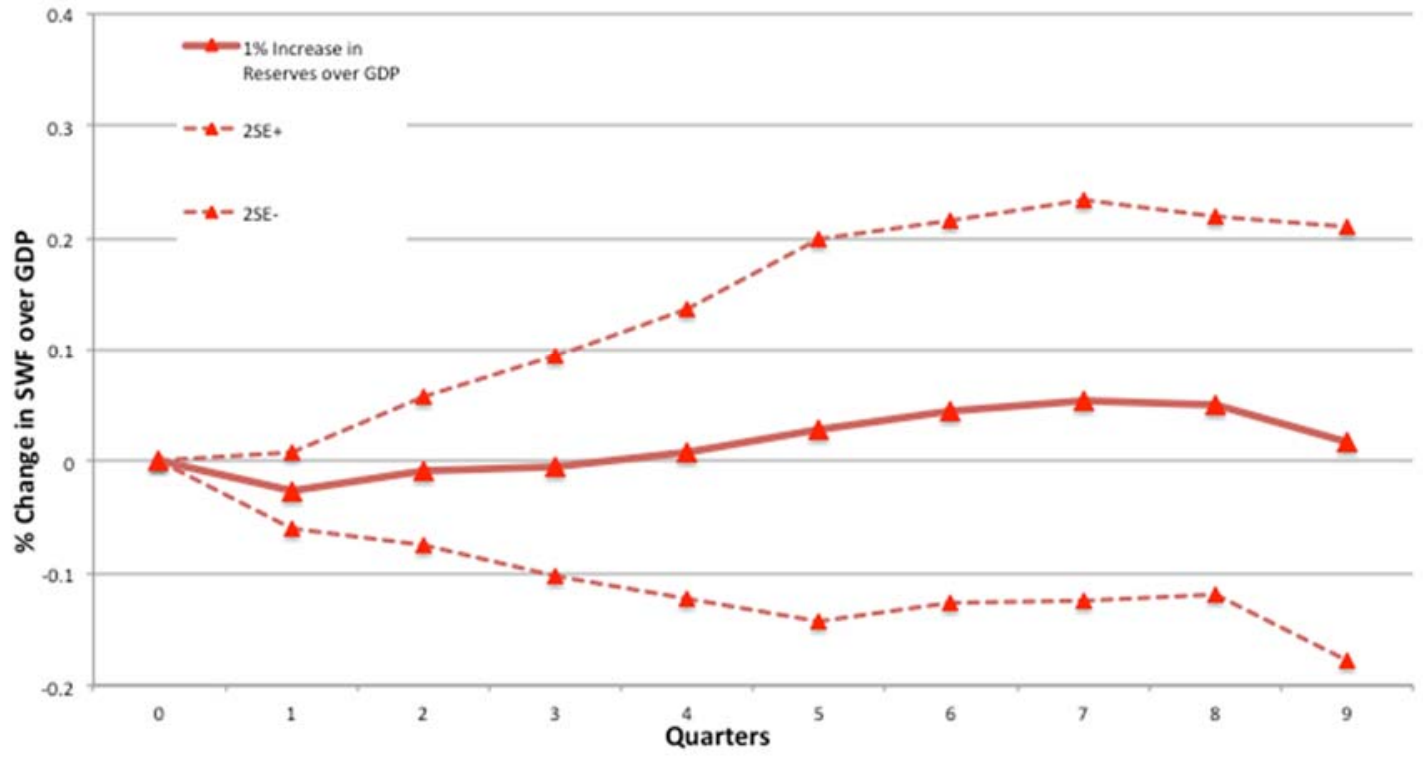


Figure 8: REER IRF to 1\% CTOT under Inflation Rules

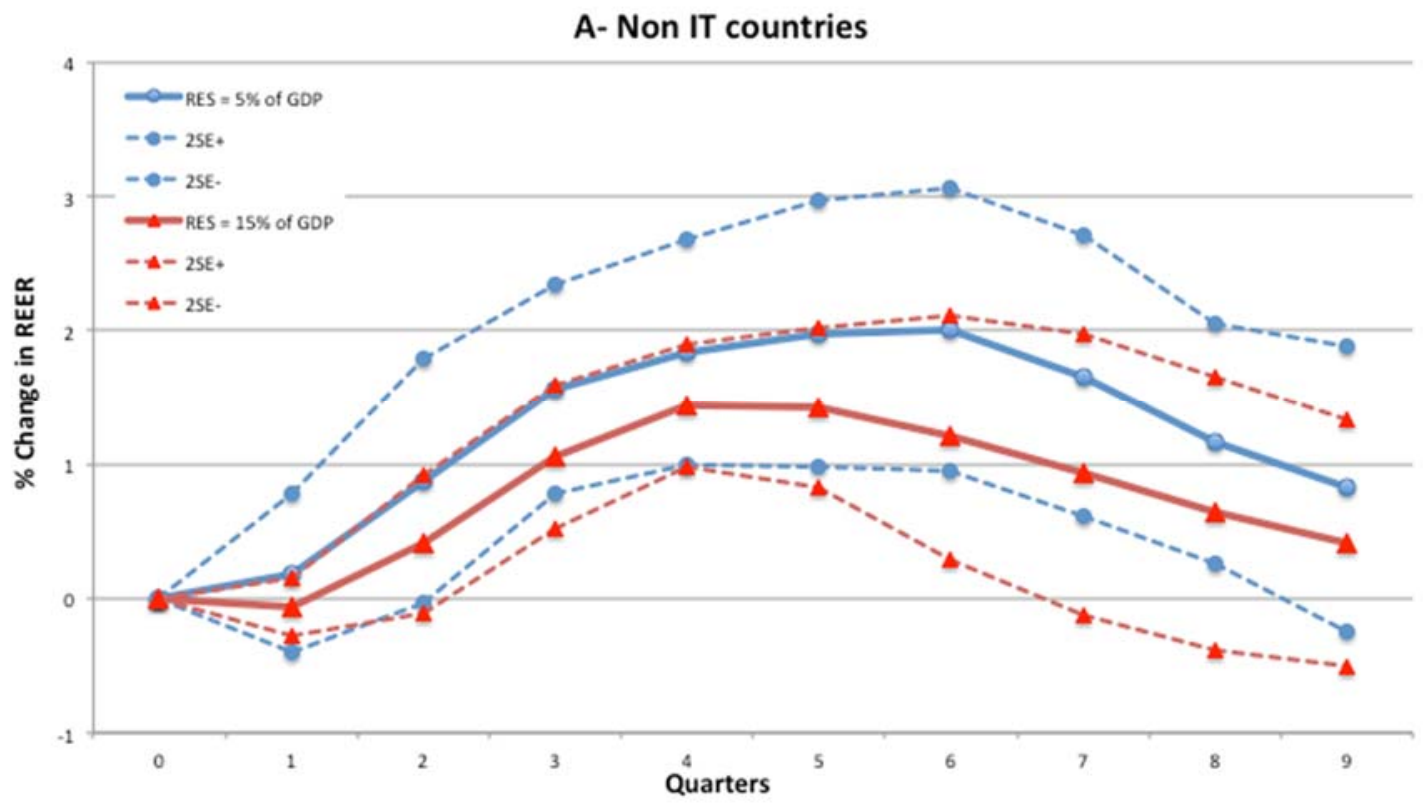

B- IT countries

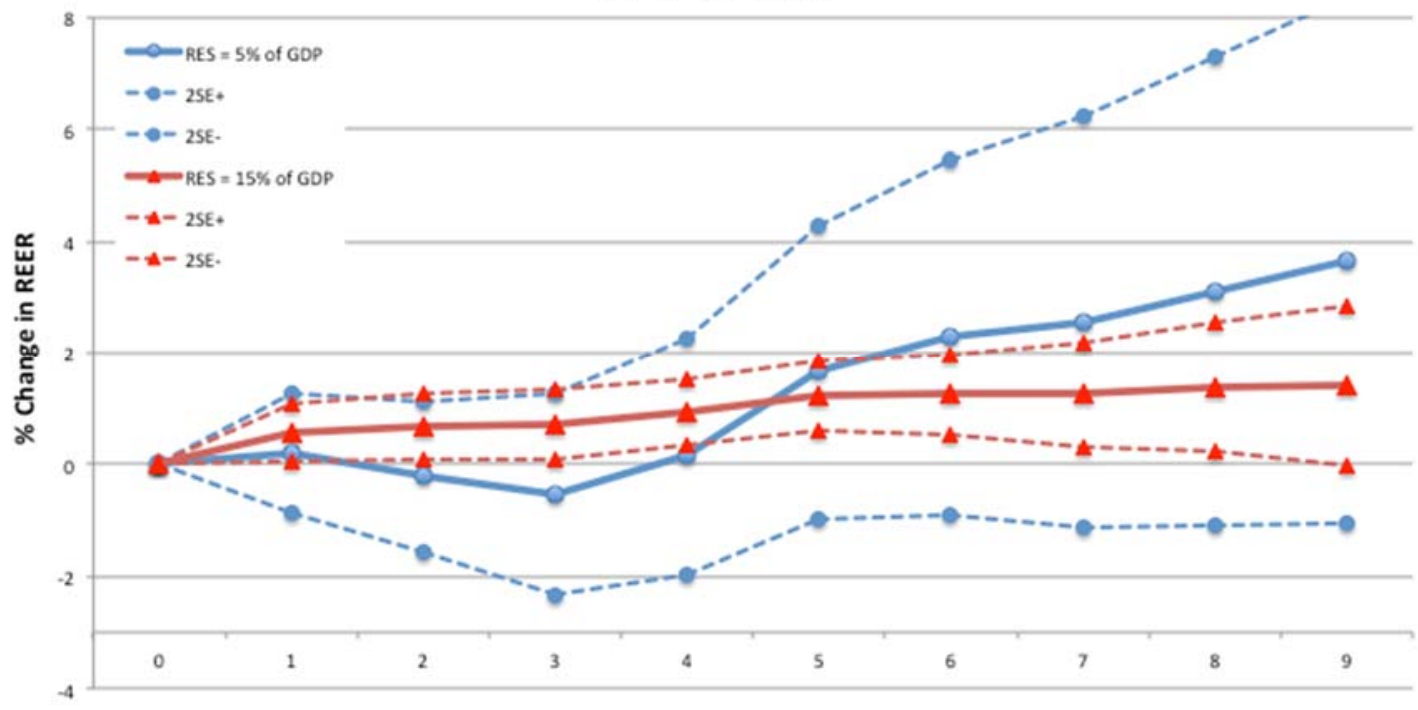

Quarters 